\title{
NOTES
}

\section{For the Sake of the Children: Court Consideration of Religion in Child Custody Cases}

\author{
Jennifer Ann Drobac*
}

Concerned that many courts routinely examine parents' religious beliefs and practices in child custody cases-despite First Amendment protectionsJennifer Drobac reviews pertinent federal constitutional law and recently published state custody cases. She finds that nearly sixty percent of the cases employ standards that violate the Establishment, Free Exercise, Supremacy, and Equal Protection Clauses. To protect religious freedoms while preserving the best interests of children, Drobac proposes the application of a procedure she terms "NOAH," the New Osier Actual Harm test, under which courts could not consider religion during the initial custody determination. Only later, in a bifurcated proceeding, could the court modify its original determination using the least restrictive means available, if it first found that a parent's religious beliefs or practices actually had harmed or would harm a child. Drobac concludes that NOAH would minimize constitutional violations, prevent religious bias from corrupting custody determinations, and serve the best interests of children by ensuring that the most qualified caregiver receives custody, regardless of religion.

No chapter in human history has been so largely written in terms of persecution and intolerance as the one dealing with religious freedom. From ancient times to the present day, the ingenuity of man has known no limits in its ability to forge weapons of oppression for use against those who dare to express or practice unorthodox religious beliefs. ${ }^{1}$

* Lecturer at Law, Stanford Law School; J.S.D. Candidate, Stanford Law School, 1999. J.D., Stanford Law School, 1987; A.M. (English History), Stanford University, 1987; A.B., Stanford University, 1981. I thank Janet E. Halley and Margaret H. Marr for their supportive encouragement, guidance, and suggestions. I also thank Martin Drobac, Kathleen A. Kane and the staff of the Stanford Law Review for their editorial suggestions, and Kathleen M. Sullivan for kindling a passion for First Amendment law. This note is dedicated to my daughter, Michal Jillian McDotvell.

1. Prince v. Massachusetts, 321 U.S. 158, 175-76 (1944) (Murphy, J., dissenting). 


\section{INTRODUCTION}

In August 1988, the Hamilton County Court of Common Pleas awarded custody of three-year-old Bobby Pater to his father even though the boy's mother had been his primary caretaker since his birth. ${ }^{2}$ The visitation order declared that his mother "shall not teach or expose the child to the Jehovah[']s Witnesses' beliefs in any form."'3 Four years later, a period representing more than half of little Bobby Pater's lifetime, the Ohio Supreme Court reversed this decision in Pater v. Pater. ${ }^{4}$ The Court held that a parent cannot be denied custody on the basis of her religious practices unless probative evidence demonstrates that those practices will adversely impact the child. ${ }^{5}$ The Pater case highlights the dilemma courts face in considering parents' religious beliefs when making child custody determinations: When do the best interests of the child permit a court to interfere with parents' religious liberties and their right to provide religious instruction to their children?

The First Amendment admonition that "Congress shall make no law respecting an establishment of religion, or prohibiting the free exercise thereof ..."6 ought to deflect any family law court from venturing into the amorphous realm of religious belief without the guidance of well-defined standards. That is not our contemporary experience, however. Since the adoption of the best interests of the child standard in the $1970 \mathrm{~s},{ }^{7}$ judicial inquiry into religious beliefs in child custody cases occurs frequently despite constitutional dictates. Illustratively, the Pater court held, "Today we reaffirm that a domestic relations court may consider the religious practices of the parents in order to protect the best interests of a child."8 court).

2. See Pater v. Pater, 588 N.E.2d 794, 801 (Ohio 1992) (reviewing the facts before the trial

3. Id. (quoting the trial court). The Ohio Supreme Court criticized the restrictions as being overbroad. It also noted that the Paters "are both loving parents, and no testimony seriously disputed either parent's ability to nurture Bobby." Id. at 799.

4. See id. at 801 .

5. See id.

6. U.S. CONST. amend. I. The First Amendment is applicable to the states through the Fourteenth Amendment. See, e.g., NAACP v. Alabama, 357 U.S. 449, 460-61 (1958) (freedom of association); Cantwell v. Connecticut, 310 U.S. 296, 303 (1940) (applying Free Exercise and Establishment Clauses to states).

7. See Zummo v. Zummo, 574 A.2d 1130 (Pa. Super. Ct. 1990). The Zummo court explained that custody courts introduced the best interests of the child standard in the nineteenth century. Courts continued to make custody awards based on gender preferences, however, until genderbased custody decisions were rejected by the Supreme Court in Weinberger $v$. Wiesenfeld, 420 U.S. 636, 652 (1975), and in Caban v. Mohammed, 441 U.S. 380, 389 (1979). See Zummo, 574 A.2d at 1135-37. For a discussion of the factors considered in a best interest evaluation, see text accompanying notes $46-47$ infra.

8. Pater, 588 N.E.2d at 797. 
A survey of over fifty state child custody cases since 1988 demonstrates that many courts consider the religious beliefs and practices of parents in determining custody of children. ${ }^{9}$ In so doing, these courts make religious preferences, endorsing one religion's training over either no training or another religion's training for a child. By considering the parents' religious beliefs and practices in child custody cases, many courts violate the free exercise rights of at least one of the custody contestants and risk violating the Establishment Clause.

In 1989, in Allegheny County v. Greater Pittsburgh $A C L U,{ }^{10}$ the United States Supreme Court implemented Justice O'Connor's "endorsement test" in evaluating alleged Establishment Clause violations. Under that test, an Establishment Clause violation occurs when the government "appear[s] to take a position on questions of religious belief."11 Since 1989, however, of over fifty child custody cases surveyed that address religion, not one mentions the endorsement test. ${ }^{12}$ That only two decisions ${ }^{13}$ cite the Supreme Court cases developing the endorsement test raises serious concerns that family law courts are ignoring the Supremacy and Establishment Clauses in child custody cases. The failure of family law courts to implement a relevant Supreme Court standard is a chilling revelation.

Courts need guiding rules to assist them in avoiding the constitutional hazards that surface when they consider religion in child custody cases. One proponent of continued court discretion under the best interests of the child standard, Carl E. Schneider, advocates the development of "negative rules" to facilitate custody decisionmaking:

The critics of the best-interest principle seem most worried about the use of particular factors in making custody decisions-taking a parent's sexual misconduct into account, for instance. Many of these bases for decision can easily, clearly, and cheaply be attacked by direct prohibitions. Such prohibitions have the advantage of sharply limiting judicial discretion in desired ways but only in desired ways. Discretion in other, more appropriate, areas can remain essentially unhampered. ${ }^{14}$

\section{See text accompanying notes 115-171 infra.}

10. 492 U.S. 573 (1989).

11. Id. at 594; see also id. at 593-94 ("Whether the key word is 'endorsement,' 'favoritism,' or 'promotion,' ... . [t]he Establishment Clause, at the very least, prohibits government from appearing to take a position on questions of religious belief . . .." (citing Lynch v. Donnelly, 465 U.S. 668,687 (1984) (O'Connor, J., concurring))).

12. See text accompanying notes $115-171$ infra.

13. See Osteraas v. Osteraas, 859 P.2d 948, 953 (Idaho 1993) (using endorsement test language but applying a different test); Zummo v. Zummo, 574 A.2d 1130, 1134, 1151-52, 1154 n.44 (Pa. Super. Ct. 1990) (citing to endorsement test cases).

14. Carl E. Schneider, Discretion, Rules, and Law: Child Custody and the UMDA's BestInterest Standard, 89 MiCH. L. REV. 2215, 2296 (1991). 
This note suggests a "negative rule" prohibiting the consideration of religion at the initial custody determination phase. The court may then consider religion only if it finds that the religious practices of the parent chosen in the initial phase have harmed or are certain to harm the child. Such a procedural and evidentiary rule would help prevent courts from making determinations that violate the First Amendment. ${ }^{15}$

Part I of this note reviews Supreme Court treatment of a parent's right to raise her child and related First Amendment cases dealing with Free Exercise and Establishment Clause issues. This part demonstrates that courts must engage in a strict scrutiny analysis when considering a parent's religion in a child custody case. Under this standard, courts can interfere with the free exercise rights of parents only to safeguard the health and safety of children, a compelling state interest. This part also tracks the development of the endorsement test in Establishment Clause cases, and explains how this analysis makes court examination of religion in child custody cases particularly problematic. ${ }^{16}$ Specifically, the mere appearance of endorsing religion in child custody determinations may violate the Establishment Clause. Analysis of Supreme Court jurisprudence supports the use of a "negative rule," prohibiting family law courts from considering religion absent actual harm to a child from religious practices.

Part II analyzes recent child custody cases that considered a parent's religious practices. This analysis separates the surveyed cases into four groups based on the standards the courts used in determining custody: actual harm cases, substantial threat cases, risk cases, and relevant issue cases. This part discusses how effectively, or ineffectively, the different standards operate in light of the preceding constitutional analysis. Part II concludes that only the actual harm standard passes constitutional muster.

Part III, proposes what I call the New Osier-Actual Harm (NOAH) procedure-a standard designed to help ensure that courts do not violate the Free Exercise or Establishment Clauses in child custody cases. ${ }^{17}$ Under NOAH, religious issues would be excluded from an initial child custody determination. Only after the initial determination, in a bifurcated proceeding, would the court consider parental religious beliefs and practices. In this sec-

15. Cf. Mitchell A. Tyner, Religious Freedom Issues in Domestic Relations Law, 8 B.Y.U. J. PUB. L. 457, 475-76 (1994). Tyner endorsed the 1980 Osier procedural model, as does this note, but he left intact the "substantial endangerment" standard of the original model. This note rejects the substantial endangerment standard (analogous to the substantial threat test discussed herein) and endorses instead the actual harm standard. Additionally, Tyner did not exhaustively analyze the Supreme Court cases that justify modifying the Osier model.

16. See text accompanying notes $75-78$ infra.

17. This test draws upon the test the Maine Supreme Court applied in Osier v. Osier, 410 A.2d 1027 (Me. 1980). The major difference is that Osier applied a substantial threat test in the second phase, while NOAH requires a showing of actual harm to the child. See text accompanying notes 172-173 infra. 
ond phase, only upon a predicate finding that religious beliefs and practices were actually harming a child (a risk of harm would not suffice) could the court modify its original determination. However, in so doing, the court would be limited to using the least restrictive means available.

Part IV applies the NOAH test to some sample child custody cases and demonstrates how it would improve their results. This part explains how the elements of the NOAH procedure would enhance custody determinations when issues such as religious discrimination, child abuse, differing parental religious beliefs, and relocation arise. Within the confines of the best interests of the child standard, nationwide implementation of the NOAH procedure, which is less prone to discretionary abuse and easier to implement than vaguer standards, will protect cherished First Amendment and parental rights.

\section{PARENTAL RIGHTS AND THE FIRST AMENDMENT}

\section{A The Free Exercise Clause}

The United States Supreme Court has long recognized the right of parents to raise their children as they deem best. In 1944, the Court held, in Prince v. Massachusetts, ${ }^{18}$ "It is cardinal with us that the custody, care and nurture of the child reside first in the parents, whose primary function and freedom include preparation for obligations the state can neither supply nor hinder."19 Decades of decisions reaffirming this tenet "have by now made plain beyond the need for multiple citation that a parent's desire for and right to 'the companionship, care, custody, and management of his or her children' is an important interest that 'undeniably warrants deference and, absent a powerful countervailing interest, protection." 20

That right is not absolute, however. The Prince Court weighed parental rights, coupled with free exercise rights, against the powerful countervailing interest of the state in safeguarding the welfare of children. In affirming a guardian's criminal conviction for violating child labor laws by directing her niece to distribute Jehovah's Witness literature on a street corner, the Court reasoned that "neither rights of religion nor rights of parenthood are beyond

18. 321 U.S. 158 (1944).

19. Id. at 166 (citing Pierce v. Society of Sisters, 268 U.S. 510 (1925)).

20. Lassiter v. Department of Soc. Servs., 452 U.S. 18, 27 (1981) (appointment of counsel not constitutionally required for indigent parents in every proceeding to terminate parental status) (quoting Stanley v. Illinois, 405 U.S. 645, 651 (1972) (unmarried fathers who have cared for their children have a due process right to a hearing before children are declared wards of the state)); see also Michael H. v. Gerald D., 491 U.S. 110, 141-42 (1989) (Brennan, J., dissenting) (arguing that the interest "of a parent and child in their relationship with each other ... was among the first that this Court acknowledged in its cases defining the 'liberty' protected by the Constitution"). 
limitation."21 Critical to the Court's holding was that Sarah Prince had violated an otherwise valid, secular child labor law. ${ }^{22}$ The Court distinguished the regulation of children from that of adults, finding that "[t]he state's authority over children's activities is broader than over like actions of adults." 23 Moreover, the Court emphasized the public nature of the activity regulated-child labor-while also noting that the Court has "respected the private realm of family life which the state cannot enter."'24

The Prince Court was careful to instruct lower courts not to interpret its decision as carte blanche authority to trample parental and free exercise rights. The Court admonished:

Our ruling does not extend beyond the facts the case presents. We neither lay the foundation "for any [that is, every] state intervention in the indoctrination and participation of children in religion" which may be done "in the name of their health and welfare" nor give warrant for "every limitation on their religious training and activities." The religious training and indoctrination of children may be accomplished in many ways .... These [Court-acknowledged ways] and all others except the public proclaiming of religion on the streets ... remain unaffected by the decision. ${ }^{25}$

Clearly, the Court intended its decision to be construed narrowly and in a manner consistent with the peculiar facts at hand. The Prince Court thus justified state usurpation of both the parental authority of a Jehovah's Witness and her free exercise rights because the exercise of those rights conflicted directly with child labor laws.

The next landmark decision to address religious and parental rights was Wisconsin v. Yoder. ${ }^{26}$ There, the Supreme Court invalidated state action similar to that in Prince when it considered the right of the Old Order Amish to keep their children home from public schools after the eighth grade. Despite the existence of a valid, secular law mandating public school attendance, the Court held that "[a] regulation neutral on its face may, in its application, nonetheless offend the constitutional requirement for governmental neutrality if it unduly burdens the free exercise of religion."27 The Court also found that the free exercise of religious beliefs includes the right to direct the religious upbringing of one's children.28 In essence, the Court granted an exception from state educational requirements for Amish religious practices.
21. Prince, 321 U.S. at 166.
22. See id. at 168-69.
23. Id. at 168 .
24. Id. at 166.
25. Id. at 171 (quoting the dissenting opinions) (first alteration in original).
26. 406 U.S. 205 (1972).
27. Id. at 220 (citing Sherbert v. Verner, 374 U.S. 398 (1963)).

28. See id. at 232-34 (identifying parents' interest in the religious education of their children as fundamental); see also Pierce v. Society of Sisters, 268 U.S. 510, 535 (1925) ("[T]hose who nurture [the child] and direct his destiny have the right, coupled with the high duty, to recognize and 
The Yoder Court took great pains to distinguish Prince. First, the Court noted how the "evils" associated with child labor motivated the Prince decision. ${ }^{29}$ In contrast, the Court opined that a child's early withdrawal from public school did not pose any threat to social welfare or the child's physical or mental health. ${ }^{30}$ Second, the Yoder Court emphasized that if it pronounced judgment in favor of the state as it did in Prince, the state would "in large measure influence, if not determine, the religious future of the [Amish] child[ren]."31 The Prince Court apparently did not fear such a result.

The Yoder Court also clarified the standard applicable in these types of cases. When balancing the free exercise claims of the parents against the state's interest, courts must apply heightened scrutiny. ${ }^{32}$ The Yoder decision suggests that absent a showing that a parent's actions will "jeopardize" the child's health or safety, a court may not regulate or restrict the religious behaviors of the parent:

[W] hen the interests of parenthood are combined with a free exercise claim of the nature revealed by this record, more than merely a "reasonable relation to some purpose within the competency of the State" is required to sustain the validity of the State's requirement under the First Amendment. To be sure, the power of the parent, even when linked to a free exercise claim, may be subject to limitation under Prince if it appears that parental decisions will jeopardize the health or safety of the child, or have a potential for significant social burdens. ${ }^{33}$

prepare him for additional obligations."); Employment Div., Dep't of Human Resources v. Smith, 494 U.S. 872, 881 (1990) (noting, in dicta, the right of parents to direct the religious upbringing of their children). Describing the development of this right, the Yoder Court stated:

The history and culture of Westem civilization reflect a strong tradition of parental concern for the nurture and upbringing of their children. This primary role of the parents in the upbringing of their children is now established beyond debate as an enduring American tradition. If not the first, perhaps the most significant statements of the Court in this area are found in Pierce $v$. Society of Sisters....

The duty to prepare the child for "additional obligations," referred to by the [Pierce] Court, must be read to include the inculcation of moral standards, religious beliefs, and elements of good citizenship.

Yoder, 406 U.S. at 232-33 (quoting Pierce, 268 U.S. at 534-35).

29. See Yoder, 406 U.S. at 229-30.

30. See id. at 230 (citing Jacobson v. Massachusetts, 197 U.S. 11 (1905)).

31. Id. at 232; cf. Pierce, 268 U.S. at 535 ("[Liberty] excludes any general power of the State to standardize its children by forcing them to accept instruction from public teachers only. The child is not the mere creature of the State....").

The Yoder Court distinguished the Amish case from one in which the children and parents might have divergent religious interests and preferences. See Yoder, 406 U.S. at 230-31 (noting that such a conflict was not at issue in the case).

32. See Yoder, 406 U.S. at 233-34.

33. Id. The Court also noted that where it had rejected free exercise challenges to regulations, "[t]he conduct or actions so regulated have invariably posed some substantial threat to public safety, peace or order." Id. (quoting Sherbert v. Vemer, 374 U.S. 398, 402-03 (1963)). 
The Yoder Court was wary of "intrusion by a State into family decisions in the area of religious training...."34

While Yoder and Prince focus on parental rights and free exercise claims, neither directly applies to court consideration of religion in child custody cases. The caveat in Prince cautions that the decision only limits parents' rights to employ their children to proclaim religion on the streets; the decision does not address the myriad other ways parents indoctrinate their children. ${ }^{35}$ The Yoder facts, involving a state statute mandating public education, also differ significantly from the circumstances attendant to judicial selection of parental custodians. Additionally, in Yoder and Prince, parents faced criminal prosecution for the violation of valid, secular laws regulating their children's conduct.

The state's action is quite different when parents dissolve their marriage. The state judiciary becomes involved in such a proceeding to settle a private dispute, not because of any violation of state law. 36 Certainly, the state retains an interest in protecting children in custody disputes, but this interest is arguably no greater than the state's interest in protecting the children of all types of households, functional and coherent, or dysfunctional and incoherent. Even in a dissolution proceeding, the state must extend the deference to parental dominion acknowledged by Yoder and Prince. ${ }^{37}$

Yoder and Prince nonetheless offer guidance to anticipate the Supreme Court's response to consideration of religion in child custody cases. Under Yoder, a court must presume the primacy of the parental right to raise and educate children. This parental right and the free exercise of religious beliefs include the right to manage the religious indoctrination of one's children. ${ }^{38}$ Only jeopardy to the health or safety of the child or a substantial threat to public safety justifies state interference with these parental First Amendment rights. ${ }^{39}$ Under Yoder, judicial interference with these rights would be reviewed with strict scrutiny.

However, in 1990 the Court moved away from Yoder's heightened scrutiny standard, in Employment Division, Department of Human Resources of

34. Id. at 231. The Court further explained that "the values of parental direction of the religious upbringing and education of their children in their early and formative years have a high place in our society." Id. at 213-214.

35. See Prince v. Massachusetts, 321 U.S. 158, 171 (1944); see also text accompanying note 25 supra.

36. See Robert H. Mnookin, Child Custody Adjudication: Judicial Functions in the Face of Indeterminacy, 39 LAW \& CONTEMP. PROBS. 226, 229 (1975) (seminal criticism of a broad best interests test as being indeterminate and speculative).

37. See Yoder, 406 U.S. at 232-234 (parents' fundamental interest in determining children's religious upbringing); Prince, 321 U.S. at 166 ("care and nurture of the child reside first in the parents"); see also note 28 supra and accompanying text.

38. See Yoder, 406 U.S. at 232-33; see also note 34 supra.

39. See Yoder, 406 U.S. at 233-34; see also text accompanying note 33 supra. 
Oregon v. Smith. ${ }^{40}$ The Smith Court held that a state law prohibiting the sacramental use of a hallucinogen does not violate the Free Exercise Clause, stating, "[w]e have never held that an individual's religious beliefs excuse him from compliance with an otherwise valid law prohibiting conduct that the State is free to regulate." 41 Kent Greenawalt explains the holding:

In Smith, the Court held that religious claimants have no special privileges in respect to laws of general application. If a reasonable law is neither directed against a religious practice nor discriminates among religious groups, it may be validly applied against people with religious objections. The state need not satisfy any test beyond the easy task of showing that the law is otherwise valid. ${ }^{42}$

The Smith decision fails to provide clear guidance for child custody cases for three reasons. First, the Smith Court specifically distinguished Yoder and like cases as involving free exercise rights in addition to parental rights. The Court explained:

The only decisions in which we have held that the First Amendment bars application of a neutral, generally applicable law to religiously motivated action have involved not the Free Exercise Clause alone, but the Free Exercise Clause in conjunction with other constitutional protections, such as ... the right of parents, acknowledged in Pierce $v$. Society of Sisters, to direct the education of their children ....43

Although the hybrid analysis in Smith may have been a "make-weight" to justify a lower level of judicial scrutiny, 44 it does distinguish Yoder and suggests that cases like Yoder, involving both parental and free exercise rights, should continue to receive strict scrutiny.

Second, like Yoder and Prince, Smith grappled with a religious practice that violated an otherwise neutral criminal law. The Smith Court stated, "Conscientious scruples have not, in the course of the long struggle for re-

40. 494 U.S. 872 (1990) (denying unemployment compensation to state employee who was discharged for ceremonial use of peyote did not violate the Free Exercise Clause). Justices O'Connor, Breyer, and Souter have contended that Smith has little precedential value and may have been wrongly decided. See City of Boerne v. P.F. Flores, 117 S. Ct. 2157, 2176, 2186 (1997) (O'Connor, Souter, Breyer, JJ., dissenting). Boerne, which held that Congress lacked the constitutional authority to pass the Religious Freedom Restoration Act, did not specifically overturn Smith, however.

41. Smith, 494 U.S. at $878-89$.

42. Kent Greenawalt, Quo Vadis: The Status and Prospects of "Tests" Under the Religion Clauses, 1995 SUP. CT. REV. 323, 334 (1995). While Greenawalt contends that Smith "sharply reduce[s] the significance of the Free Exercise Clause," he also notes that the clause may protect "religious objectors [who] also claim[] parental rights." Id.

43. Smith, 494 U.S. at 881 (citing Wisconsin v. Yoder, 406 U.S. 205 (1972)) (some citations omitted). The Smith Court did not include Prince in the list of hybrid cases. The exclusion of Prince is inconsistent with the plain language of that case. See Prince v. Massachusetts, 321 U.S. 158,166 (1944); see also text accompanying notes 18-20 supra.

44. See Greenawalt, supra note 42 , at 335 ("Assessing the relevance of the 'combination' or 'hybrid' analysis in Smith is hard. Most scholars assume this language was a make-weight to 'explain' Yoder that lacks enduring significance."). 
ligious toleration, relieved the individual from obedience to a general law not aimed at the promotion or restriction of religious beliefs." 45 As noted earlier, though, child custody disputes do not typically involve questions of whether religious principles justify a violation of law. Rather, the issue is whether in applying a standard of general applicability-the best interests of the child standard-the court may consider the competing parents' religious practices.

Under the best interests of the child standard, courts can consider all factors that affect a child's physical, emotional, intellectual, moral, and (sometimes) spiritual welfare. ${ }^{46}$ Such factors include: which parent is more closely bonded to the child, which parent feeds, clothes, bathes, and plays with the child, which parent takes the child to the doctor and dentist, which parent assists with homework and attends school functions, and which parent can meet the needs of the child generally. A court may also consider where the child will live and attend school, whether the child has supportive friends and extended family in the area, whether the child will be injured by parental feuding or by radically new circumstances, and any preferences that a teenager may have regarding custody. ${ }^{47}$ Thus, courts can investigate the intimate details of the parents' lives that may impact the well-being of the child. Ultimately, the court selects a custodian who will better meet the child's needs. If both parents are equally qualified, the court awards the parents joint custody.

That the best interests of the child standard is intended to be, and may even appear to be, facially neutral, does not mean that it is neutral in its application, or that court consideration of religion is uniformly constitutional. ${ }^{43}$ The Supreme Court has struck down what appear to be facially neutral laws when they are applied only against a particular religion. Subsequent to the Smith decision, in Church of the Lukumi Babalu Aye, Inc. v. City of

45. Smith, 494 U.S. at 879 (quoting Minersville Sch. Dist. v. Gobitis, 310 U.S. 586, 594-95 (1940), overruled by West Virginia State Bd. of Educ. v. Barnette, 319 U.S. 624 (1943)).

46. See, e.g., Kammerer v. Martin, No. 95-0665, 1995 WL 723249, at***6 n.5 (Wis. Ct. App. Dec. 7,1995 ) (quoting Wisconsin statutory law concerning the factors to consider during a custody determination); Zummo v. Zummo, 574 A.2d 1130, 1137 (Pa. Super. Ct. 1990) (discussing best interests factors generally).

47. While observing family law courts in session, I have heard all of these factors considered during a best interests analysis. See generally UNIF. MARRIAGE AND DIVORCE ACT $\S 402,9 A$ U.L.A. 561 (amended 1973) (best interests of child standard); Daniel B. Griffith, The Best Interests Standard: A Comparison of the State's Parens Patriae Authority and Judicial Oversight in Best Interests Determinations for Children and Incompetent Patients, 7 ISSUES L. \& MED. 283, 291-301 (1991) (discussing best interests inquiry in child custody proceedings); Andrea Charlow, Awarding Custody: The Best Interests of the Child and Other Fictions, 5 YALE L. \& POL'Y REV. 267, 267-73 (1987) (criticizing the standard as overly vague and subject to abuse).

48. See Capitol Square Review \& Advisory Bd. v. Pinette, 515 U.S. 753, 777 (1995) (O'Connor, J. concurring) ("[T]he Establishment Clause forbids a State from hiding behind the application of formally neutral criteria and remaining studiously oblivious to the effects of its actions."). 
Hialeah, ${ }^{49}$ the Supreme Court determined that a ban on killing animals violated the free exercise rights of Santeria adherents who practice animal sacrifice as a form of religious devotion. ${ }^{50}$ Even though the Court found the challenged ordinances facially neutral, it noted that the laws specifically targeted Santería sacrifice. 51 The Court held that "[f]acial neutrality is not determinative. ... . Official action that targets religious conduct for distinctive treatment cannot be shielded by mere compliance with the requirement of facial neutrality. The Free Exercise Clause protects against governmental hostility which is masked as well as overt." 52

Neither hostility to a specific religion nor atheism motivated the adoption of the best interests of the child standard. When courts deliberately consider religion in child custody determinations, however, they take a facially neutral standard and, with their broad discretion, use it to promote one religion over another or one religion over no religion. Thus, juxtaposed against Lukumi, Smith offers little guidance for child custody courts. Together they may even demonstrate that the neutrality of the best interests standard can best be safeguarded by prohibiting the consideration of benign religious practices altogether.

The third way Smith fails to provide guidance in child custody disputes relates to its rejection of heightened scrutiny review. The Smith Court justified its rejection of the strict scrutiny standard in evaluating alleged free exercise violations by reasoning, "The government's ability to enforce generally applicable prohibitions of socially harmful conduct, like its ability to carry out other aspects of public policy, 'cannot depend on measuring the effects of a governmental action on a religious objector's spiritual development."'53 The Court explained that it invoked the compelling interest (strict scrutiny) test to evaluate free exercise claims only when the government had created a mechanism for individualized exemptions to generally applicable laws. ${ }^{54}$ For instance, in unemployment compensation cases, such as Sherbert $v$. Verner, ${ }^{55}$ the unemployment compensation administrative system allowed the state to analyze individual free exercise claims for exemption. ${ }^{56}$ Smith noted that such cases "stand for the proposition that where the State has in place a system of individual exemptions, it may not refuse to extend that

49. 508 U.S. 520 (1993).

50. See id.

51. See id. at 535-540.

52. Id. at 534.

53. Employment Div., Dep't of Human Resources v. Smith, 494 U.S. 872, 885 (1990) (quoting Lyng v. Northwest Indian Cemetery Protective Ass'n, 485 U.S. 439, 451 (1988)).

54. See id. at 884.

55. 374 U.S. 398 (1963).

56. See id. at 405-06. 
system to cases of 'religious hardship' without compelling reason."'57 In Smith, no mechanism existed for the evaluation of free exercise claims against the otherwise valid and neutral Oregon criminal drug laws, and the Court refused to extend the heightened scrutiny standard to that type of case. Smith thus provides little guidance to child custody courts, since the state does appear to have a system of individual exemptions in place for child custody cases.

The best interests standard requires a case-by-case, individualized analysis of the needs of the children and the relative talents and merits of both parents. $^{58}$ This is exactly the kind of system referred to in Smith that permits individual free exercise exemptions. Thus, any denial of custody and resulting free exercise claims should afford the claimant a strict scrutiny review. As Prince held over fifty years ago, ${ }^{59}$ the state should have to demonstrate a sufficiently compelling, countervailing governmental interest to warrant restriction or denial of the parent's custody rights based on religious beliefs and practices. We have come full circle.

\section{B. The Constitutionality of Custody Cases-A Free Exercise Analysis}

The Yoder decision confirmed that the free exercise right to indoctrinate a child with religious principles is part of the parental bundle of rights. ${ }^{60} \mathrm{~A}$ state can interfere with that right only if there is a "substantial threat" of "harm to the physical or mental health of the child." 61 Nothing suggests that this free exercise right dissipates when the parents are in conflict in a child custody case. ${ }^{62}$

The state facilitates marital dissolution, in part, to provide assurances that during the process at least one adult continues to support and care for the children of the marriage, preventing their abandonment and becoming wards of, and financial burdens upon, the state. When parents cannot agree who will be primarily responsible for the children, the state decides. Unless it is responding to specific allegations of harm to children, the state will otherwise rarely intercede to regulate the care and maintenance of children. For

57. Smith, 494 U.S. at 884 (quoting Bowen v. Roy, 476 U.S. 693, 708 (1986)).

58. See text accompanying notes $46-47$ supra.

59. See text accompanying notes 19-24 supra.

60. See Wisconsin v. Yoder, 406 U.S. 205, 233 (1972).

61. Id. at 230.

62. Parents do not lose parental authority vis-a-vis the state when they separate from each other. See, e.g., Caban v. Mohammed, 441 U.S. 380, 388-94 (1979) (state law requiring the unmarried biological mother's, but not the unmarried biological father's ability to withhold consent to child's adoption violates Equal Protection); Stanley v. Illinois, 405 U.S. 645 (1972) (unwed fathers have a due process right to a hearing on parental fitness before children are declared state wards following the mother's death); Armstrong v. Manzo, 380 U.S. 545, 546-50 (1965) (divorced parent has a procedural due process right to notice of adoption proceedings by stepfather). 
example, the state would not be likely to dictate which married parent is to provide childcare, regulate the hours each parent spends with the children, plan meals, organize family holidays and vacations, specify the school children must attend, direct the religious training of the children, or other matters of like kind. ${ }^{63}$

When divorced or unmarried parents fail to agree on child custody, the state chooses a custodian by evaluating the beliefs and behaviors of each applicant to determine who will better care for the child. In so doing, the state employs the best interests of the child standard. ${ }^{64}$ When a court evaluates parental religious practices, however, it should also use the reasoning and methodology formulated in Yoder. The Yoder Court acknowledged the free exercise right of the Amish to indoctrinate their children, and then examined the state's competing interest in having children attend school. The Court found that compulsory school attendance protects children by preparing them to be self-sufficient individuals. ${ }^{65}$ It is also intended to protect our political system by creating an educated citizenry. ${ }^{66}$ The Court held, however, that the one or two years of public education the Amish children would miss "would do little to serve those [state] interests."67

Using the Yoder reasoning, the inquiry in a child custody case should center on whether the free exercise rights, or the benign religious indoctrination practices ${ }^{6 s}$ of potential guardians, hinder or promote the state's goal of

63. See Moore v. City of East Cleveland, 431 U.S. 494, 499 (1977) (acknowledging a "private realm of family life which the state cannot enter" (quoting Prince v. Massachusetts, 321 U.S. 158, 166 (1944))); Zummo v. Zummo, 574 A.2d 1130, 1140 (Pa. Super. Ct. 1990). The Zummo court suggested: "Parents in healthy marriages may disagree about important matters; and, despite serious, even irreconcilable, differences on important matters, the government could certainly not step in, choose sides, and impose an orthodox uniformity in such matters to protect judicially or bureaucratically determined "best interests' of the children of such parents." Id. (citing Parham v. J.R., 442 U.S. 584 (1979)).

64. Cf. Reno v. Flores, 507 U.S. 292, 303-04 (1993) (upholding INS regulation mandating custody of potentially deportable juveniles who could not be released to guardians). The Reno court held:

"The best interests of the child," a venerable phrase familiar from divorce proceedings, is a proper and feasible criterion for making the decision as to which of two parents will be accorded custody. But it is not traditionally the sole criterion-much less the sole constitutional criterion-for other, less narrowly channeled judgments involving children, where their interests conflict in varying degrees with the interests of others.

Id. at 303-04.

65. See Yader, 406 U.S. at 221.

66. See id.

67. Id. at 222.

68. I focus on benign practices since the Yoder Court clearly distinguishes parental decisions that jeopardize the health or safety of the child. See id. at 230 . Those decisions invoke different state interests and transform the court from private dispute mediator to child protector.

One might argue that a parent's failure to engage in religious practices for the child's spiritual welfare, such as baptism, for example, might jeopardize the safety of the child by jeopardizing her soul. Under separation of church and state, however, the state's interest extends only to the child's 
ensuring care for children. Some Americans may believe there is a correlation between particular religious views and practices and superior childcare talents. ${ }^{69}$ However, an argument that, in general, Jews, Pagans, Hindus, or theists make better or worse caretakers than Catholics, Muslims, Zoroastrians, and atheists, is dubious at best. ${ }^{70}$ Moreover, any court that would dare to dabble in such an evaluation would surely risk violating the Establishment Clause. ${ }^{71}$

A family law court can satisfy the state goal of ensuring adequate childcare even if it ignores the benign religious practices of custodial candidates. Thus, consideration of benign religious practices does little to further the state's interest in child custody cases. It follows, under Yoder, that courts cannot justify the violation of free exercise rights of parents in a child custody context absent a substantial threat of harm to the child from the parent's religious practices.

\section{The Establishment Clause}

Consideration of religion in child custody cases also raises Establishment Clause concerns, particularly when courts confer custodial rights on a parent

temporal well-being. See, e.g., Everson v. Board of Educ., 330 U.S. 1, 17-18 (1947) (sustaining state reimbursement for cost of transporting children to parochial schools as an extension of the logic by which state-paid police protect schoolchildren regardless of whether they attend parochial schools).

Whatever spiritual consequences may be visited upon the child by parental practices are beyond the state's responsibility even if they remain within the state's sphere of influence. Moreover, the Establishment Clause specifically prevents the state from asserting its influence. In Lee v. Weisman, 505 U.S. 577 (1992), Justice Blackmun wrote in his concurrence:

We have believed that religious freedom cannot exist in the absence of a free democratic government, and that such a government cannot endure when there is fusion between religion and the political regime. We have believed that religious freedom cannot thrive in the absence of a vibrant religious community and that such a community cannot prosper when it is bound to the secular. And we have believed that these were the animating principles behind the adoption of the Establishment Clause. To that end, our cases have prohibited government endorsement of religion, its sponsorship, and active involvement in religion, whether or not citizens were coerced to conform.

Id. at 609 (Blackmun, J., concurring); see also Employment Div., Dep't of Human Resources v. Smith, 494 U.S. 872, 887 (1990) (warning that "courts must not presume . . . the plausibility of a religious claim").

69. For example, a parent once advised me against hiring an au pair or English nanny to care for my daughter. She explained that Mormon girls provide better childcare because Mormonism emphasizes the domestic parenting role for women of that faith.

70. But cf. Donald. L. Beschle, God Bless the Child?: The Use of Religion as a Factor in Child Custody and Adoption Proceedings, 58 FORDHAM L. REV. 383, 408 (1989) ("Empirical studies have shown that [a child's] well-being is clearly furthered by 'transcendence, or the capacity to find purpose and meaning beyond one's self and the immediate,' but that traditional theism is not the sole path to achieving that capacity." (quoting Ellison, Spiritual Well-Being: Conceptualization and Measurement, J. PSYCHOL. \& THEOLOGY 330, 338 (1983))).

71. See text accompanying notes 72-102 infra. 
with one particular religious faith rather than on the parent with another or no faith. ${ }^{72}$ In Everson v. Board of Education, ${ }^{73}$ the Court evaluated the First Amendment's Establishment Clause and held, "Neither a State nor the Federal Government can set up a church. Neither can pass laws which aid one religion, aid all religions, or prefer one religion over another."74

The Court perfected a test to determine whether governmental action violates the Establishment Clause in Lemon v. Kurtzman. ${ }^{75}$ The three-part Lemon test requires that governmental action must: (1) "have a secular legislative purpose," (2) have a "principal or primary effect . . . that neither advances nor inhibits religion," and (3) avoid "an excessive . . . entanglement with religion."76 However, Supreme Court Justices, constitutional law scholars, and others have criticized the Lemon test in the two decades since its formulation. ${ }^{77}$ Greenawalt cautions that judges "should recognize that the Supreme Court has definitely abandoned Lemon."78

72. The Fourteenth Amendment governs state courts (including family law courts) and judicial officers. A court's conferring custody based on religious considerations is state action that could violate the Establishment Clause. See Wallace v. Jaffree, 472 U.S. 38, 49 (1985) (legislators may not "interfere with the individual's freedom to believe, to worship, and to express himself in accordance with . . . his own conscience"); Shelley v. Kraemer, 334 U.S. 1, 14 (1948) ("action of state courts and judicial officers in their official capacities is to be regarded as action of the state within the meaning of the Fourteenth Amendment").

73. 330 U.S. 1 (1947).

74. Id. at 15; see also Wallace, 472 U.S. at 52-53 (affirming that the First Amendment freedoms encompass the personal choice of any or no religion); Kathleen M. Sullivan, Foreword: The Justices of Rules and Standards, 106 HARV. L. REV. 22, 36 (1992) (arguing that the Establishment Clause "must cover some non-coercive forms of governmental favoritism toward religion-that is, endorsement"). This neutrality principle continues to dominate Establishment Clause jurisprudence. See, e.g., Rosenberger v. University of Virginia, 515 U.S. 819, 820-21, 841, 845 (1995).

75. 403 U.S. 602 (1971). Lemon invalidated a $15 \%$ salary supplement to private school teachers of secular subjects. See id. at 606-07.

76. Id. at 612-13 (quoting Walz v. Tax Comm'n, 397 U.S. 664, 674 (1970)).

77. See, e.g., Wallace, 472 U.S. at 63 (Powell, J., concurring) (referring to criticism by Justices O'Connor and Rehnquist); Greenawalt, supra note 42, at 359-79 (reviewing the fractured application of Lemon in subsequent cases). Donald Beschle comments, "Separationists find the [Lemon] test too loose in its acceptance of plausible secular state purposes and too pliable in its quest for a primary secular effect. Accomodationists point to the 'Catch-22' nature of the entanglement clause as an obstacle to conscientious legislative attempts to satisfy the "effects' test." Beschle, supra note 70 , at 394.

78. Greenawalt, supra note 42, at 361. But see Agostini v. Felton, 117 S. Ct. 1997, 2016 (1997) (holding that federal funding of remedial instruction by government employees to children at sectarian schools does not violate Establishment Clause). In overturning Aguilar v. Felton, 473 U.S. 402 (1985), and parts of the companion case, School Dist. of Grand Rapids v. Ball, 473 U.S. 373 (1985), the Agostini Court reviewed the Ball Court application of the Lemon test. See Agostini, $117 \mathrm{~S}$. Ct. at 2008-17.

The Agostini Court noted that "the general principles we use to evaluate whether government aid violates the Establishment Clause have not changed since Aguilar was decided." Id. at 2010. The Court evaluated the effect and entanglement aspects of the federal funding and found no Establishment Clause violation. Id. at 2009-16. The Court also concluded, "The same considerations that justify this holding [Agostini] require us to conclude that this carefully constrained program 
While theorists have contemplated several alternative tests to determine Establishment Clause violations, ${ }^{79}$ the O'Connor "endorsement test" has received the most sustained interest. ${ }^{80}$ In Lynch $v$. Donnelly, ${ }^{81}$ Justice O'Connor suggested that the Establishment Clause prohibits two types of government action. In her concurring opinion, she explained:

One is excessive entanglements with religious institutions, which may interfere with the independence of the institutions, give the institutions access to government or governmental powers not fully shared by nonadherents of the religion, and foster the creation of political constituencies defined along religious lines. The second and more direct infringement is government endorsement or disapproval of religion. Endorsement sends a message to nonadherents that they are outsiders, not full members of the political community, and an accompanying message to adherents that they are insiders, favored members of the political community. Disapproval sends the opposite message. ${ }^{82}$

The first prohibition closely resembles the third prong of the Lemon test, warning against "excessive entanglement." However, the second admonition-that government action must neither endorse nor disapprove of religion-is significantly different from the first two prongs of Lemon.

The Lemon purpose and effects prongs focus literally on the stated purpose and actual effects of governmental action or legislation. In her explanation of the endorsement test, Justice O'Connor advised, "The proper inquiry under the purpose prong of Lemon, I submit, is whether the government intends to convey a message of endorsement or disapproval of religion."83 In applying the endorsement test, a court asks what the government intends by its action, which is not necessarily the same as the stated purpose. Justice O'Connor also counseled:

[T] he effect prong of the Lemon test is properly interpreted not to require invalidation of a government practice merely because it in fact causes, even as a primary effect, advancement or inhibition of religion.... What is crucial is that

also cannot reasonably be viewed as an endorsement of religion." Id. at 2016. Thus, the Court sanctioned the use of both the Lemon and endorsement tests.

Whether the Court will employ the Lemon test in future Establishment Clause cases remains to be seen. The Court may have used the Lemon test in Agostini only to parallel the contrasting reasoning of the Aguilar and Ball cases.

79. See generally Greenawalt, supra note 42 (reviewing the application of several recent tests under the Religion Clauses).

80. See, e.g., County of Allegheny v. ACLU, 492 U.S. 573, 595 (1989) (adopting Justice O'Connor's endorsement test for the first time). Greenawalt explains, however, "A majority of Justices do agree that 'endorsement' is the crucial inquiry for certain kinds of cases, but no majority agrees on the proper formulation of that test for at least some of these cases." Greenawalt, supra note 42 , at 361 .

81. 465 U.S. 668 (1984). In Lynch, the Court found that a city did not violate the Establishment Clause by displaying a nativity scene. See id. at 684-85.

82. Id. at $687-88$ (O'Connor, J., concurring) (citations omitted).

83. Id. at 691 . 
a government practice not have the effect of communicating a message of government endorsement or disapproval of religion. ${ }^{84}$

This explanation emphasizes that the unconstitutionality of a message lies in its perception as government endorsement, and not in whether the government has, in reality, advanced or inhibited religion. This test, which ferrets out the appearance of inappropriate endorsement, sweeps much more broadly than one that requires actual advancement or inhibition of religion.

In Wallace v. Jaffree, $\$ 5$ Justice O'Connor further clarified the endorsement test. She said in her concurrence, "The relevant issue is whether an objective observer, acquainted with the text, legislative history, and implementation of the statute, would perceive it as a state endorsement . . . ."86 Who is Justice O'Connor's intelligent objective observer? Not an "average" person on the street, but one who, for example, is familiar with the legislative history of a statute.

Justice O'Connor gave more guidance concerning the objective observer in Corporation of the Presiding Bishop of the Church of Jesus Christ of Latter-Day Saints v. Amos. ${ }^{87}$ She noted that something more than historical facts determine whether the objective observer perceives a message of endorsement: "Although evidentiary submissions may help answer it, the question is, like the question whether racial or sex-based classifications communicate an invidious message, in large part a legal question to be answered on the basis of judicial interpretation of social facts." 88 This elaboration leaves the qualifications of the objective observer frustratingly vague and confusing. O'Connor's objective observer is the "reasonable person" in tort law who, unlike the personification of community ideals, understands complex statutes and their legislative histories. This observer can both personify community ideals and engage in sophisticated judicial interpretation of the social elements he or she personifies. What remains unclear, in part, is

S4. Id. at 691-92. Justice O'Connor added, "Every government practice must be judged in its unique circumstances to determine whether it constitutes an endorsement or disapproval of religion." Id. at 694.

S5. 472 U.S. 38 (1985).

S6. Id. at 76 (O'Connor, J., concurring); see also Corporation of the Presiding Bishop of the Church of Jesus Christ of Latter-Day Saints v. Amos, 483 U.S. 327, 348 (1987) (O'Connor, J., concurring) (citing Wallace and discussing the objective observer's perception of government action); Thomton v. Caldor, 472 U.S. 703, 711 (1985) (O'Connor, J., concurring) (referencing the objective observer's understanding of a state endorsing one particular day as the Sabbath).

87. 483 U.S. 327 (1987).

88. Id. at 348 (O'Connor, J., concurring) (quoting Lynch, 465 U.S. at 693-94). In Capitol Square Review \& Advisory Bd. v. Pinette, 515 U.S. 753 (1995), Justice O'Connor wrote, "In this respect, the applicable observer is similar to the 'reasonable person' in tort law, who 'is not to be identified with any ordinary individual, who might occasionaily do unreasonable things' but is 'rather a personification of a community ideal of reasonable behavior, determined by the [collective] social judgment."' Id. at 779-80 (O'Connor, J., concurring) (quoting W. KEETON, D. DOBBS, R. KeETON \& D. OWEN, PROSSER AND KEETON ON LAW OF TORTS 175 (5th ed. 1984)). 
whether (and how) the objective observer represents all communities and how she harmonizes the reasonable person's conclusions with those of the judicial historian and interpreter. ${ }^{89}$

The Amos objective observer might examine court consideration of religion in child custody disputes and receive "an invidious message" similar to those associated with "racial or sex-based classifications."90 In Palmore v. Sidoti, ${ }^{91}$ the Court invalidated the withdrawal of custody of an infant from a mother because she remarried a man of a different race. ${ }^{92}$ The Court ruled, "Such [racial] classifications are subject to the most exacting scrutiny; to pass constitutional muster, they must be justified by a compelling governmental interest and must be 'necessary . . . to the accomplishment' of their legitimate purpose."93

Is court consideration of religion necessary to accomplish the purpose of selecting a custodian in a child custody case? Before the adoption of the best interests of the child standard, courts routinely decided custody cases without considering religion. Thus, religious classifications are not necessary to accomplish the task of choosing a custodian. ${ }^{94}$ When domestic relations courts

\footnotetext{
89. In describing his notion of the reasonable observer, Justice Stevens opined:

It is especially important to take account of the perspective of a reasonable observer who may not share the particular religious belief it expresses. A paramount purpose of the Establishment Clause is to protect such a person from being made to feel like an outsider in matters of faith, and a stranger in the political community....

$\cdots$

... Justice $O^{\prime}$ Connor ... presumes a reasonable observer so prescient as to understand legal doctrines that this Court has not yet adopted.
}

Capitol Square, 515 U.S. at 799, 802 n.7 (Stevens, J., dissenting). But see id. at 779 (O'Connor, J., concurring) ("In my view, proper application of the endorsement test requires that the reasonable observer be deemed more informed than the casual passerby postulated by Justice Stevens.").

Kent Greenawalt suggests:

Further, since feelings of exclusion among members of minorities are so important, and since the majority (Christians) take cultural dominance so much for granted that they may not perceive endorsement of their position, judges should attend especially to how reasonable members of minorities may react. For cases in which actual reactions are the vital concern, Justices should not impute to "reasonable people" a knowledge of legal and political matters that far exceeds that of ordinary people.

Greenawalt, supra note 42, at 374 (footnotes omitted).

90. Amos, 483 U.S. at 348 (quoting Lynch, 465 U.S. at 693-94).

91. 466 U.S. 429 (1984).

92. See id. at 434.

93. Id. at 432-33 (quoting McLaughlin v. Florida, 379 U.S. 184, 196 (1964)). The Pater court relied upon Palmore when it said, "[A] court may well violate the parent's constitutional rights if its decision is improperly based on religious bias. The United States Constitution and the Ohio Constitution forbid state action which interferes with the religious freedom of its citizens or prefers on religion over another." Pater v. Pater, 588 N.E.2d 794, 798 (Ohio 1992) (citation omitted).

94. See Beschle, supra note 70, at 384-89 (discussing how the determination of custody has historically included several factors but not religion); see also Zummo v. Zummo, 574 A.2d. 1130 , 1135-37 (Pa. Super. Ct. 1990) (discussing the history of "presumptive" standards used in child custody cases before adoption of best interests standard). 
do consider religion, as when they consider race, their classifications and conclusions should be subject to the "most exacting scrutiny."

Finally, when courts consider the religious affiliations of potential custodians, they risk violating the neutrality principle by choosing one parent over another, unless the parents' religious beliefs are exactly alike. ${ }^{95}$ "The clearest command of the Establishment Clause is that one religious denomination cannot be officially preferred over another."96 The neutrality requirement referred to here is similar to the one imposed in Board of Education of Kiryas Joel Village School District v. Grumet. ${ }^{97}$

The Kiryas Joel Court invalidated a statute that created a special school district for Satmar Hasidim, disciples of a strict sect of Judaism. The Court focused on the impermissible delegation of civil authority and held, "[T]he difference [between what is permissible] lies in the distinction between a government's purposeful delegation on the basis of religion and a delegation on principles neutral to religion, to individuals whose religious identities are incidental to their receipt of civic authority." 98

One can fashion an analogy to Kiryas Joel in child custody cases. In choosing a custodian, the family law court determines to whom the state will delegate its parens patriae $e^{99}$ authority. Rather than make children of dissolving families wards of the state in cases where parents cannot decide who will care for them, the state delegates its authority to the parent who will serve the best interests of the children. Kiryas Joel stands for the proposition that a state may not "deliberately delegate discretionary power to an individual, institution, or community on the ground of religious identity." 100 It follows that a court may not delegate parental duties on the basis of religious identity. This analogy spotlights the lack of neutrality courts display when they consider religious affiliations in delegating their parens patriae authority by choosing a custodian.

The Kiryas Joel Court emphasized, "[W]e have frequently relied explicitly on the general availability of any benefit provided religious groups or

95. See note 74 supra.

96. Larson v. Valente, 456 U.S. 228, 244 (1982); see also Torasco v. Watkins, 367 U.S. 488 , 495 (1961) ("Neither [a State nor the Federal Government] can constitutionally pass laws or impose requirements which aid all religions as against non-believers, and neither can aid those religions based on a belief in the existence of God as against those religions founded on different beliefs." (footnote omitted)).

97. 512 U.S. 687 (1994).

98. Id. at 699.

99. "Parens patriae originates from the English common law where the King had a royal prerogative to act as guardian to persons with legal disabilities such as infants, idiots and lunatics. In the United States, the parens patriae function belongs with the states." BLACK's LAW DICTIONARY 1114 (6th ed. 1990).

100. Kiryas Joel, 512 U.S. at 699. 
individuals in turning aside Establishment Clause challenges."101 When courts consider the religion of contestants in child custody disputes, they deny a benefit generally available to both parents-custodial rights-based on religion. Thus, court consideration of religious beliefs in custody disputes necessarily results in a judicial preference of one religion over another, unless the parents' religious beliefs are exactly alike. Moreover, such judicial preferences also send the message of endorsement, thereby violating the Establishment Clause. ${ }^{102}$

\title{
D. The Constitutionality of Custody Cases-An Establishment Clause Analysis
}

It is stunning that not one of fifty-three recent child custody cases involving religion specifically referred to the O'Connor endorsement test, first adopted by a Supreme Court majority almost a decade ago. ${ }^{103}$ Several of the cases used endorsement test language but made no thorough endorsement test evaluation. ${ }^{104}$ Few cited or applied the virtually abandoned Lemon test. ${ }^{105}$

\begin{abstract}
101. Id. at 704. The Court continued:
In Walz v. Tax Comm'n of City of New York, 397 U.S. 664, 673 (1970), for example, the Court sustained a property tax exemption for religious properties in part because the State had "not singled out one particular church or religious group or even churches as such," but had exempted "a broad class of property owned by nonprofit, quasi-public corporations." And Bowen v. Kendrick, 487 U.S. 589, 608 (1988), upheld a statute enlisting a "wide spectrum of organizations" in addressing adolescent sexuality because the law was "neutral with respect to the grantee's status as a sectarian or purely secular institution." See also Texas Monthly, Inc. v. Bullock, 489 U.S. 1 (1989) (striking down sales tax exemption exclusively for religious publications); Estate of Thornton v. Caldor, Inc., 472 U.S. 703, 711 (1985) (O'CONNOR, J., concurring in judgment) (statute impermissibly "singles out Sabbath observers for special . . . protection without according similar accommodation to ethical and religious beliefs and practices of other private employees").
\end{abstract}

Id. at 704-05 (footnote and some citations omitted).

102. In Capitol Square Review \& Advisory Board v. Pinette, 515 U.S. 753 (1995), Justice Stevens wrote: "The Establishment Clause does not merely prohibit the State from favoring one religious sect over others. It also proscribes state action supporting the establishment of a number of religions, as well as the official endorsement of religion in preference to nonreligion." Id. at 809 (Stevens, J., dissenting) (citing Wallace v. Jaffree, 472 U.S. 38, 52-55 (1985)). But see Beschle, supra note 70, at 397 ("In broad terms, then, religion is considered to be a proper subject of inquiry in custody disputes."); $i d$. at 401 ("Religion may be a factor in custody cases even in the absence of a denominational split between parents. In such cases, courts have often attempted to determine which parent would provide the better religious atmosphere for the child.").

103. See County of Allegheny v. ACLU, 492 U.S. 573, 595 (1989) (adopting the endorsement test as providing a "sound analytical framework for evaluating government use of religious symbols").

104. See, e.g., McCown v. McCown, 649 A.2d 418, 422 (N.J. Super. Ct. App. Div. 1994). In $\mathrm{McCown}$, the court declined to modify a decree of joint custody to provide that the children attend Hebrew day school rather than private school after the mother converted to Orthodox Judaism. See id. The court reasoned, "The orders which we affirm endorse neither the religion nor the culture of either parent but are intended to insure that the children have the opportunity to participate in the cultural household routine and religious practices of both parents." Id. (emphasis added). While 
This lack of influence by the Court is significant because the differences between the Lemon and endorsement tests could produce differing results when applied to court consideration of religion in child custody cases. Under the Lemon test, court determination of which parent will serve the best interests of the child as custodian has a secular purpose: to guarantee that children obtain adequate care following the dissolution of the marriage and do not become financial burdens on the state. It is doubtful that courts intend to endorse or inhibit religion in the process, but this will be explored later, in Part IV. ${ }^{106}$

The second prong of the Lemon test requires that the "principal or primary effect" of governmental action "neither advance[] nor inhibit[] religion."'107 The principal effect of the best interests evaluation is the selection of a qualified caregiver. ${ }^{108}$ One could argue that any advancement or inhibition of religion is incidental ${ }^{109}$ or simply an accommodation of the religious needs of the parties. ${ }^{110}$ One could also argue that religion is neither advanced nor

the McCown court cited no U.S. Supreme Court authority, it used the comfortably familiar word "endorse" as it refused to require religious school attendance. The court explained, "Neither we, nor the courts below, approve nor disapprove of the conversion. The courts do not choose between religions." Id.

105. See text accompanying notes $75-78$ supra. See also, e.g., Osteraas v. Osteraas, 859 P.2d 948, 953 (Idaho 1993); Zummo v. Zummo, 574 A.2d 1130, 1146 n.26 (Pa. Super. Ct. 1990); Burrows v. Brady, 605 A.2d 1312, 1315 (R.I. 1992).

106. But see Beschle, supra note 70, at 406 (discussing "possible secular purposes and effects that might support the use of religion . . . in child custody . . . determinations"); Johns v. Johns, 918 S.W.2d 728, 731 (Ark. Ct. App. 1996). In Johns, the father appealed a modification requiring him to take his children to Sunday school and church. The court justified the restriction of the father's visitation time based on religious instruction furthering the best interests of the children. The court explained:

Because appellant [the father] has the right to visit his children every other week, his refusal to see that they attend Sunday School and worship services would mean they would miss half of the possible opportunities for the moral instruction that their mother has been trying to instill. Although we express neither approval nor disapproval for whatever religious beliefs the children may be learning, the fact remains that appellant offered no alternative method for instructing his children in moral values during the time that they would have otherwise been receiving that instruction through Sunday School and church attendance.

Id. Thus, the court rationalized its restriction by suggesting that it was merely interested in the children's moral education. Unfortunately, the court does not avoid the appearance of the endorsement of religion over nonreligion. The substitution of the word "moral" for "religious" should not save this case from First Amendment purview.

107. Lemon v. Kurtzman, 403 U.S. 602,612 (1971).

108. The "best interests" of the child are not necessarily the primary effect. No court foresees the future as a soothsayer or prophet. All a court knows for certain is that it designates a guardian, hopefully the best one available for the child.

109. See Capitol Square Review \& Advisory Bd. v. Pinette, 515 U.S. 753 (1995), wherein the Court held: "as a matter of Establishment Clause jurisprudence, we have consistently held that it is no violation of government to enact neutral policies that happen to benefit religion." Id. at 764 .

110. See Board of Educ. of Kiryas Joel Village Sch. Dist. v. Grumet, 512 U.S. 687, 705 (1994) ("[W]e do not deny that the Constitution allows the State to accommodate religious needs by alleviating special burdens."); Corporation of the Presiding Bishop of the Church of Jesus Christ of Latter-Day Saints v. Amos, 483 U.S. 327, 334 (1987). 
inhibited generally since, for example, atheists as well as Hindus, Pagans and fundamentalist Christians receive custody of their children in individual cases. We have no clear evidence that courts discriminate against any particular religious group or against atheists in awarding custody. ${ }^{111} \mathrm{But}$, in any given case, choosing a Hindu over a Jewish parent, or a Catholic over a Pagan, offers the appearance of endorsing Hindu or Catholic views over the competing parents' views.

Some courts might opine that the objective observer will understand that the court's consideration of religion in custody cases is in furtherance of the child's best interests, and is not a particular endorsement of one religion over another. Some scholars have argued that religious training of any kind benefits children. That view may or may not be correct. ${ }^{112}$ The fact remains that in choosing between competing religions, the judiciary necessarily adds its imprimatur to one religion, to the detriment of the other. Such a ruling necessarily creates an appearance of judicially approved religious beliefs and practices and, therefore, implicates the Establishment Clause. ${ }^{113}$

111. The number of cases like Pater v. Pater, 588 N.E.2d 794 (Ohio 1992), however, involving parents who are Jehovah's Witnesses, suggests discrimination against this particular faith occurs in family law courts. See, e.g., note 134 infra and accompanying text.

112. See, e.g., Beschle, supra note 70, at 410-11. Beschle argues that, broadly defined, religion generates mental and emotional well-being in children and therefore serves a secular interest. This argument is problematic. The Supreme Court has held that the posting of the Ten Commandments served secular purposes too, but still violated the Establishment Clause. See Stone v. Graham, 449 U.S. 39, 41 (1980).

Additionally, Beschle confuses whose job it is to generate the mental and emotional wellbeing of children. The parents or custodians play this role. The state does so only by default when it finds the parents unfit. Because courts use the best interests standard to determine who will act as guardian, Beschle's analysis should focus on whether consideration of religion has a legitimate purpose and effect in choosing a skilled caregiver. I would argue that it does not. For example, a skilled, loving, and attentive Hindu caregiver should be able to provide for a Jewish child. Furthermore, such consideration certainly gives the impression that government is endorsing religion.

Finally, Beschle suggests:

If the definition of religion is expanded, or if a narrowly defined religion is one of several factors in establishing a commitment to a value system transcending self-interest, the establishment clause should be no bar to the use of religion as a factor in determining the best interests of the child. This use of religion has a legitimate secular purpose and effect, treats traditional religion no better or worse than competing systems of ultimate values, and does not endorse traditional religion.

Beschle, supra note 70, at 419. This use of religion may not endorse traditional religion but it does endorse Beschle's version of "religion." Moreover, the entanglement that will result both from a court's analysis of which religions promote the transcendence of self-interest and from regulating the use of religion will render his scheme unconstitutional under all tests.

113. For scholarly discussions of the Establishment Clause implications in child custody disputes, see Beschle, supra note 70, at 416-26 (consideration of "religion" in broad sense does not violate the Establishment Clause); R. Collin Mangrum, Exclusive Reliance on Best Interest May Be Unconstitutional: Religion as a Factor in Child Custody Cases, 15 CREIGHTON L. REV. 25, 51-62, 72-74 (1981) (suggesting that courts may consider which parent better serves a child's religious needs, as long as they do not evaluate the merits of a particular religion); Steven M. Zarowny, The Religious Upbringing of Children After Divorce, 56 NOTRE DAME L. REV. 160, 164-66 (1980) 
The objective observer must remember that the best interests of the child standard is one that merely facilitates the determination of which parent will better care for the children of the dissolving marriage. ${ }^{114}$ Religion is no more a gauge of child raising proficiency than is gender or race. In the absence of evidence that a parent's particular religious affiliation harms a child, court consideration of the parent's religious views and practices appears to be an unwarranted violation of the Establishment Clause.

\section{RECENT CHILD CUSTODY CASES}

\section{A. The Four Categories}

Given the constitutional rights of parents, one might wonder how family law courts consider religion in light of the Free Exercise and Establishment Clauses. Family law courts vary in their interpretation and application of constitutional law when making custody determinations in the best interests of the child. Some states allow courts to consider the child's spiritual life as a factor. ${ }^{115}$ Some courts evaluate which parent better fosters the child's religious training. ${ }^{116}$ Other states allow their courts to consider religious beliefs and practices in determining the general qualifications of a custodian. ${ }^{117}$

(arguing that a judge can hide religious motivations within the discretion accorded under the best interests standard); Note, The Establishment Clause and Religion in Child Custody Disputes: Factoring Religion into the Best Interest Equation, $82 \mathrm{MrCH}$. L. REV. 1702 (1984) (arguing that consideration of religion is only constitutional where the child has religious convictions of her own).

114. See, e.g., Zummo v. Zummo, 574 A.2d 1130, 1138 (Pa. Super. Ct. 1990). The Zummo court explained:

The statist notion that the government may supercede parental authority in order to ensure bureaucratically or judicially determined "best interests" of children has been rejected as repugnant to American traditions. Parham v. J.R., 442 U.S. 584, 603 (1979); accord Meyer v. Nebraska, 262 U.S. 390, 401-02 (1923) (rejecting the models of Aristotelian guardianship and Spartan state collectivization of youth as antithetical to American freedoms). Judges and state officials are deemed ill-equipped to second-guess parents, and are precluded from intervening in absence of "powerful countervailing interests." Lassiter v. Dep't of Soc. Servs., 452 U.S. $18,27(1981)$.

Id. (some citations omitted). But see Beschle, supra note 70, at 406 ("Most child custody decisions acknowledge that ensuring the child's best interests is the goal of such proceedings."). However, Beschle loses sight of the fact that courts do not have free reign to provide for the best interests of the child. Courts must choose parents who will serve in the child's best interests.

115. See, e.g., Zummo, 574 A.2d at 1142 (trial courts are required to consider all factors which bear on a child's "spiritual well-being" when making a custody decision); Burrows v. Brady, 605 A.2d 1312, 1315 (R.I. 1992) (the child's spiritual as well as moral and physical well-being is important).

116. See, e.g., Aldous v. Aldous, 99 A.D.2d 197, 199 (N.Y. App. Div. 1984) (considering religion when a child has developed religious ties and when "those needs can be better served by one parent than the other").

117. See, e.g., Gancas v. Schultz, 683 A.2d 1207, 1213 (Pa. Super. Ct. 1996) ("Religion while not determinative, 'is an important matter and should be given some consideration in child custody matters."' (quoting Boylan v. Boylan, 577 A.2d 218, 219 (Pa. Super. Ct. 1990), overruled on other grounds by G.B. v. M.M.B., 670 A.2d 714 (Pa. Super. Ct. 1996)). 
Many courts consider religious practices only when acts threaten to harm a child, ${ }^{118}$ and some courts exclude consideration of religion unless specific behaviors actually harm a child. ${ }^{119}$

To understand state implementation of federal constitutional law, I studied a number of child custody cases decided after 1988 to evaluate whether states were acknowledging or reflecting the endorsement test, which entered Establishment Clause jurisprudence in 1989.120

The cases separate into four categories, depending on the level of the risk of harm to a child that a party must demonstrate before a court will base its custody decision on the religious beliefs and practices of the contestants: (1) actual harm, (2) a substantial threat of harm, (3) only some risk of harm, or (4) no risk at all, suggesting that religion is always a relevant factor to be considered by the court. ${ }^{121}$ In no case did a court specifically acknowledge

118. See, e.g., In re Marriage of Gersovitz, 779 P.2d 883, 885 (Mont. 1989) ("[C]ourts will examine religious practices which interfere with the child's general welfare."); Palmer v. Palmer, 545 N.W.2d 751, 755 (Neb. 1996) (limiting parental rights only when "religious practices "pose an immediate and substantial threat to a child's temporal well-being"' (quoting LeDoux v. LeDoux, 452 N.W.2d 1, 5 (Neb. 1990))).

119. See, e.g., In re Marriage of Weiss, 49 Cal. Rptr. 2d 339 (Ct. App.), cert. denied, 117 S. Ct. 509 (1996) (relying on Yoder to uphold joint custody when father could not show that mother's religious activities substantially harmed the child); Osteraas v. Osteraas, 859 P.2d 948 (Idaho 1993) (endorsing the principle that courts should not consider religion in custody disputes without compelling reasons, such as the effect of a dispute over religion on a child's welfare); Pater v. Pater, 588 N.E.2d 794 (Ohio 1992) (emphasizing that parents have a right both to free exercise of their religion and to educate their children).

120. See note 13 supra and accompanying text.

121. Scholars examining custody decisions group them in a variety of ways. See, e.g., Tyner, supra note 15, at 471 (dividing cases into those which treat religion as part of a multi-factor analysis and those which require special circumstances before religion can be considered). I do not group cases by state because it may be misleading to place a state in a particular group based solely on recent custody decisions. For example, Gago v. Acevedo, 625 N.Y.S.2d 250 (App. Div. 1995), De Luca v. De Luca, 609 N.Y.S.2d 80 (App. Div. 1994), and Marjorie G. v. Stephen G., 592 N.Y.S.2d 209 (Sup. Ct. 1992), might lead one to believe that New York does not consider religion unless a parent's religious practices are actually harming a child

In 1984, however, the appellate division, in Aldous v. Aldous, 473 N.Y.S.2d 60 (App. Div. 1984) established a test for considering religion in child custody cases:

When presented as an issue, religion may be considered as one of the factors in determining the best interest of a child, although it alone may not be the determinative factor . . . New York courts will consider religion in a custody dispute when a child has developed actual religious ties to a specific religion and those needs can be served better by one parent than the other ... when a religious belief violates a State statute ... and when a religious belief poses a threat to a child's well-being....

Id. at 62 (citations omitted). Thus, while Gago, De Luca, and Marjorie G. suggest that New York belongs in Group 1 because the courts based their decisions on a requirement of actual harm, Aldous would be in Group 4-relevant issue cases-because of the first prong of the Aldous test. This first prong does not require actual harm or illegal behavior (the second prong) before the court can consider the parents' religion.

Within New York, then, there is no strict rule as to when a court may consider religion. This suggests that decisions may be inconsistent within the state. New New York cases, relying on Aldous, for instance, could place that state in Group 4 . The only way to determine the relative po- 
and implement the endorsement test. Indeed, only two courts even cited the cases developing the endorsement test. ${ }^{122}$

\section{Group 1: actual harm cases.}

Tables I and II (see appendix) ${ }^{123}$ include cases in which religion became a factor in the best interests evaluation only when a parent's religious practices (1) actually harmed a child or (2) would harm a child in the future. ${ }^{124}$ Twenty-two of the fifty-three cases studied (41\%) fall into Group 1.

Pater v. Pater, ${ }^{125}$ the case that introduces this note, provides a good example of decisions in this category. ${ }^{126}$ The Pater court began its analysis with the proposition that "court[s] may consider the religious practices of the parents in order to protect the best interests of a child."127 The court then engaged in an informative discussion of free exercise rights and the fundamental right of parents to educate their children. ${ }^{128}$ The court cited Prince for the counterpoint that a compelling state interest justifies interference with these rights. ${ }^{129}$ The Pater court then concluded that "the state's compelling interest in protecting children from physical or mental harm clearly allows a

sitions of all fifty states is through a state-by-state exhaustive survey, which is beyond the scope of this note.

122. See note 13 supra.

123. I have placed custody modification cases in tables separate from original custody decisions for several reasons. First, this note suggests that religion should not be part of the original determination of custody. After the initial determination or in a modification, I agree that court consideration of religion is appropriate to accommodate free exercise claims and to make limited restrictions in response to actually harmful practices. Second, the issues are typically narrower in modification cases because custody has already been determined. Finally, modifications may involve different standards than initial determinations of custody. For example, many courts require a material change of circumstances before they will consider making a modification. Having made this cautionary remark, I will not separate modifications into distinct subsets in the text because many of the issues they address are identical to those in original custody determinations.

124. Group 1-actual harm cases-does not include cases in which there is a risk of harm to the child. Some courts, however, required a threshold level of harm before the court allowed religious beliefs and practices to influence the custody determination. See, e.g., Kendall v. Kendall, 687 N.E.2d 1228, 1232 (Mass. 1997), petition for cert. filed, 66 U.S.L.W. 3422 (U.S. Apr. 27, 1998) (No. 97-1756) ("The plaintiff was required to demonstrate 'in detail' that exposure to the defendant's religion caused the children 'substantial injury, physical or emotional, and [would] have a like harmful tendency for the future." (quoting Felton v. Felton, 418 N.E.2d 606, 608 (Mass. 1981))).

125. 588 N.E.2d 794 (Ohio 1992).

126. A case like Pater conceivably fits into Group 4 because of its reaffirmation that a family law court can consider the religious practices of the parents. Because the court also holds, however, that religion cannot provide the basis for a decision unless the child will actually be harmed by the practice, I placed it in Group 1.

127. Pater, 588 N.E.2d at 797.

128. See id. at 797-99.

129. See id. at 798-99. 
court to deny custody to a parent who will not provide for the physical and mental needs of the child." 130

Apparently, the trial court heard evidence concerning the mother, Jennifer Pater, and her conversion from Catholicism to the Jehovah's Witness faith. ${ }^{131}$ (The father remained Catholic.) Witnesses testified that Jennifer no longer attended Catholic Mass. ${ }^{132}$ The father's counsel interrogated Jennifer as to whether Jehovah's Witnesses salute the flag, associate with nonmembers, and celebrate holidays, among other issues. ${ }^{133}$ One expert testified that Jehovah's Witnesses experience mental illness more frequently than those of other faiths. ${ }^{134}$ The Pater high court reversed the lower courts, holding that "custody may not be denied to a parent solely because she will not encourage her child to salute the flag, celebrate holidays, or participate in extracurricular activities."135 The court noted, "Today, we adopt the majority rule that a court may not restrict a non-custodial parent's right to expose his or her child to religious beliefs, unless the conflict between the parents' religious beliefs is [negatively] affecting the child's general welfare."136

\section{Group 2: substantial threat cases.}

Zummo v. Zummo ${ }^{137}$ is a good example of a case in which the court considered whether the parents' religious beliefs posed a substantial threat to a child's welfare. In Zummo, the Pennsylvania superior court provided an incisive analysis of the current state of child custody law as it relates to religious issues, and in doing so surveyed Yoder, Allegheny, and Smith, among other cases. ${ }^{138}$ When Pamela and David Zummo married, Pamela was a practicing Jew and David was a sporadically practicing Catholic. They orally agreed to raise their children in the Jewish faith. ${ }^{139}$ The parents de-

130. Id. at 799.

131. See id. at 796.

132. See id.

133. See id. The judge excluded testimony that Jehovah's Witnesses do not allow their children to have blood transfusions as being too speculative and, therefore, irrelevant. Id. at $797 \mathrm{n} .1$; see also text accompanying notes 220-225 infra.

134. See Pater, 588 N.E.2d at 796. In response, the court said, "This testimony was a blatant attempt to stereotype an entire religion. Regardless of the rate of mental illness among an entire group, that evidence does not prove that the religion in question will negatively affect a particular individual." Id. at 800; see also text accompanying notes 157-158 infra.

135. Pater, 588 N.E.2d at 797.

136. Id. at 801. One wonders how beliefs affect a child's well-being. The Court continued, "Because a divorce is a stressful event for a child, a court must carefully separate the distress caused by that event from any distress allegedly caused by religious conflict." Id.

137. 574 A.2d 1130 (Pa. Super. Ct. 1990).

138. See id. at 1134-35.

139. See id. at 1141. 
cided to share custody of the children post-dissolution, but could not agree on the children's religious training. ${ }^{140}$

The trial court resolved the issue by placing restrictions on David's visitation rights. ${ }^{141}$ On appeal, the superior court held that agreements to raise children in a particular faith when one parent later objects are invalid. ${ }^{142}$ The court based its decision on three points:

1) such agreements are generally too vague to demonstrate a meeting of minds, or to provide an adequate basis for objective enforcement;

2) enforcement of such an agreement would promote a particular religion, serve little or no secular purpose, and would excessively entangle the courts in religious matters; and,

3) enforcement would be contrary to a public policy embodied in the First Amendment Establishment and Free Exercise Clauses (as well as their state equivalents) that parents be free to doubt, question, and change their beliefs, and that they be free to instruct their children in accordance with those beliefs. ${ }^{143}$

Relying on the notion of religious freedom, the superior court concluded, "Thus, while we agree that a parent's religious freedom may yield to other compelling interests, we conclude that it may not be bargained away."144

The language from Yoder furnishes the standard adopted in Zummo and other substantial threat cases found in Table III (see appendix). ${ }^{145}$ The

140. See id. at 1141-42.

141. See id; see also note 151 infra.

142. See Zummo, 574 A.2d at 1144; see also Abbo v. Briskin, 660 So. 2d 1157, 1161 (Fla. Dist. Ct. App. 1995) ("When the matter involves the religious training and beliefs of the child, we do not agree that the court may make a decision in favor of a specific religion over the objection of the other parent. . . A child's religion is no proper business of judges.") (citation omitted). But see Hoefers v. Jones, 672 A.2d 1299 (N.J. Super. Ct. Ch. Div. 1994), aff'd per curiam, 672 A.2d 1177 (N.J. Super. Ct. App. Div. 1996) (court enforcement of negotiated joint custody agreement in which father agreed to pay for education at religiously affiliated school did not violate Free Exercise Clause because father could still practice his faith).

143. Zummo, 574 A.2d at 1144 (citations omitted).

144. Id. at 1148; see also In re Marriage of Weiss, 49 Cal. Rptr. 2d 339 (Ct. App.), cert. denied, 117 S. Ct. 509 (1996). Before Martin and Marsha Weiss married, Marsha converted from the Baptist to the Jewish faith. At that time, she executed a document promising to raise her children as Jews. Id. at 341. The couple divorced in 1993 and received joint custody of their son. The father appealed, alleging that the trial court erred in failing to restrict Marsha's efforts to involve the child in her religious activities. Id. at 342 . Whereas the Zummo court promoted a standard that involved "a substantial threat of present or future physical or emotional harm," Zummo, 574 A.2d at 1157 (emphasis added), the Weiss court followed California precedent and dictated that courts look for "a clear affirmative showing that these religious activities [are] harmful to the [child]." Weiss, 49 Cal. Rptr. 2d at 346 (quoting Mentry v. Mentry, 190 Cal. Rptr. 843, 847). See also id. at 342 ("A parent will not be enjoined from involving a child with the parent's religious activities absent a clear and affirmative showing of harm."). The Weiss court refused to enforce the "contract," finding that "the prevention of harm to the child, which was the concern of Mentry, is a compelling state interest." Id. at 346.

145. Interestingly, more than half of the cases that appear in Table III (see appendix) hail from Nebraska. 
Zummo court summarized the standard in its opinion: "The United States Supreme Court has specifically held that parental authority in matters of religious upbringing may be encroached upon, only upon a showing of a 'substantial threat' of 'physical or mental harm to the child, or to the public safety, peace, order, or welfare."'146 Only competent evidence of a substantial threat of harm to the child, introduced by the parent requesting the restriction, would justify the restriction of the other parent. ${ }^{147}$

The Zummo court ruled, "We find that the requirement of a 'substantial threat' of 'physical or mental harm to the child' is applicable to proposed restrictions on a parent's post-divorce parental rights regarding the religious upbringing of his or her children." 148 The court held that any restriction on a parent is limited to "the least intrusive means adequate to prevent the specified harm."149 Applying these standards, the Zummo court found no substantial threat of harm to the children and concluded that both parents had the right to inculcate religious beliefs in their children. ${ }^{150}$ The court then invalidated the restriction that prevented David from taking the children to Catholic services. ${ }^{151}$

The substantial threat test differs from the actual harm test by introducing uncertainty into the evaluation. Under the actual harm test, if the child has suffered or will suffer harm in the future, a court can intervene. Words such as "risk," "endanger," "threat," "jeopardize," and "imperil," and phrases like "may harm," and "might harm" appear in the application of the substantial threat evaluation but not in the actual harm analysis. Unfortunately, many courts use the language of both tests as if they were interchangeable, or otherwise conflate the two. ${ }^{152}$

\section{Group 3: risk cases.}

In five cases surveyed, courts allowed religious affiliations to impact the custody determination when only some risk of harm threatened the children.

146. Zummo, 574 A.2d at 1138 (quoting Wisconsin v. Yoder, 406 U.S. 205, 230 (1972)).

147. See id. at 1157.

148. Id. at 1141 (citing Yoder, 406 U.S. at 205); see also id. at 1154-55. The Zummo court did not distinguish between post-dissolution parents and divorcing parents, reasoning that the threat of harm justified state interference regardless of marital status. Id. at 1139-40.

149. Id. at 1157.

150. See id.

151. See id. The court determined, however, that the trial court could designate time each Sunday for the children to attend religious activities with Pamela, as well. This allocation of time constituted an accommodation for Pamela and not a restriction of David's time. The court posited that as long as David received a fair allocation and similar accommodations, the court tread on neutral ground. Id.

152. See, e.g., id. at 1138 (using language of the actual harm test instead of that of the substantial threat test). Whenever substantial threat language justifies the final ruling, I have placed the case in Group 2-substantial threat cases. 
These cases are identified in Table V (see appendix). Constitutional law recognizes a significant difference between a substantial risk of harm as opposed to any risk of harm. Yoder, for example, required a "substantial threat" of "physical or mental harm" to the child, "or to the public safety, peace, order, or welfare."153 If a court considers religious affiliation upon a showing of only a minimal risk or some risk of harm, the threshold requirement of Yoder is likely unmet. With less than "substantial" or "imminent" or "serious" risk, the state may not have a sufficiently compelling interest to override a parent's Yoder rights.

Petersen $v$. Rogers ${ }^{154}$ typifies this category of cases and exposes the opportunity for religious discrimination and impermissible questioning by the trial court concerning religious beliefs when only some risk of harm to the child is required. ${ }^{155}$ In this case, a couple whose interlocutory adoption of a child had been set aside petitioned for custody. The trial court awarded custody to the biological parents. The appellate court reversed, reasoning that the trial court had impermissibly questioned the petitioning couple about their faith, known as The Way International.

The appellate court explained, "The general rule is that a limited inquiry into the religious practices of the parties is permissible if such practices may adversely affect the physical or mental health or safety of the child . ..."156

153. Wisconsin v. Yoder, 406 U.S. 205, 230 (1972). 1994).

154. 433 S.E.2d 770 (N.C. Ct. App. 1993), rev'd on other grounds, 445 S.E.2d 901 (N.C.

155. Cf. text accompanying notes 192-212 infra (discussing Group 4-relevant issue-cases involving religious discrimination), See, e.g., Murphy v. Murphy, No. C0-95-1363, 1996 WL 70978, at *1 (Minn. Ct. App. Feb. 20, 1996); In re Marriage of Gersovitz, 779 P.2d 883 (Mont. 1989). In Gersovitz, the father appealed a custody determination that named the mother custodian. The father argued that her selection of a non-Jewish school interfered with his right to raise the child as a Jew. The difference between this case and the substantial threat cases rests with the court's enunciated standard for consideration of religion. The court said it would "examine religious practices which interfere with the child's general welfare." Id. at 885 (emphasis added). The court found no such interference, holding, "[A]n award of custody for the purpose of religious education should not dominate other elements which comprise the best interests of this particular child." Id.

The basis of the Murphy case was a challenge to an order of custody to the mother with restrictions on the father's visitation. Both parents had belonged to a minority religious sect and had lived in a church community. After the mother left the church and community, she alleged physical and emotional abuse. The court visitation restriction prevented the father from visiting with the children on church property or in the presence of other church members. The court justified restrictions on visitation when "that visitation is likely to endanger the child's physical or emotional health or impair the emotional development of the child." Murphy, 1996 WL 70978, at *1 (emphasis added). Finding a history of physical abuse and alleged sexual misconduct, the court affirmed the restrictions. It noted that the father remained free to discuss his religion with the children during his visits. Id. at *3.

156. Peterson, 433 S.E.2d at 775 . The Petersen court specifically rejected the actual harm test:

Although some courts have only permitted evidence showing actual harm to the child, see

Quiner, 59 Cal. Rptr. at 516, we find a broader rule allowing inquiry into actual or potential 
The appellate court established that under this standard a trial court could consider the child's spiritual welfare, but could not inquire into religious beliefs. Thus, while the Peterson court itself did not engage in religious discrimination, the mere risk standard it adopted opened the door for both religious discrimination and impermissible questioning at the trial court level.

In particular, the appellate court criticized the admission of testimony from Ms. Kisser, a representative of The Cult Awareness Network:

To allow Ms. Kisser to speculate that the general practices and beliefs of members might be detrimental to children is to condemn the entire membership of The Way as unsuitable parents. .. . This result would certainly produce a chilling effect upon litigants in future cases where one spouse was a member of The Way or of some other lesser-known religion. ${ }^{157}$

This passage highlights several important points. First, it demonstrates the dubious utility of certain types of expert testimony regarding parental fitness. Second, it illustrates how discrimination against one or two individuals leads to discrimination against entire religious groups. Third, and most importantly, it clarifies that trial courts have an affirmative duty to prevent religious discrimination in the courtroom. As the Peterson court determined, a laissez-faire approach by the judiciary is unacceptable. ${ }^{158}$

As the cases in this category demonstrate, requiring only a threshold showing that a religious practice may harm a child affords the opportunity for religious inquiry and discrimination. The risk standard favors state investigation into parents' religious beliefs, thereby threatening violation of the Free Exercise and Establishment Clauses.

\section{Group 4: relevant issue cases.}

The last category of cases-relevant issue cases-includes decisions in which the court requires no actual harm, no substantial threat of harm, nor even a risk of harm before it considers a parent's religious practices. The

harm to be more desirable. See Short, 698 P.2d at 1313 (court found actual harm standard too restrictive and adopted standard of whether beliefs or practices were "reasonably likely" to cause present or future harm).

Id. (emphasis added).

157. Id. at 777 (citations omitted). In the sentence preceding this passage, the court reasoned, "Absent any evidence that Paul was adversely affected or would be adversely affected in the future by the religious practices, the court's acquiescence in the extensive inquiry was impermissible." Id. This remark uses the language of the actual harm test; however, because the court specifically disavowed the stricter test, I treated this case as a risk case. This case serves as another example of how courts sometimes create confusion by using the language of more than one standard. See text accompanying note 152 supra.

158. See also Stolarick v. Novak, 584 A.2d 1034 (Pa. Super. Ct. 1991) (rejecting trial court's decision to take children from their father's stable home based solely on his fundamentalist Christian beliefs). 
Lange case ${ }^{159}$ illustrates this standard. Robert Lange appealed a visitation restriction that granted him only supervised visitation rights until he could demonstrate that he would not "impose" his Christian fundamentalist religious views on his children. ${ }^{160}$ The appellate court affirmed the order, relying on a Wisconsin law that affords the custodial parent exclusive control over the children's religion. ${ }^{161}$

The appellate court agreed with the trial court that joint custody would not work for the Langes because Robert's religious fundamentalism caused him to insist on making all decisions. ${ }^{162}$ The court approved the choice of the mother, Elizabeth Lange, as custodian and noted that it would have ordered "reasonable visitation" for Robert but could not because he had disobeyed temporary orders restricting his religious indoctrination of the children. ${ }^{163}$ Without requiring any risk of harm to the children, the court justified the visitation restrictions:

159. Lange v. Lange, 502 N.W.2d 143 (Wis. Ct. App. 1993).

160. See id. at $144-45$.

161. See id. at 146. The court added, "[T]he custodial parent's exclusive right to choose the religion is meaningless without protection from subversion." Id; see also notes 163 \& 187 infra and accompanying text.

162. See Lange, 502 N.W.2d at 145. The Lange court also determined that Robert's "religious beliefs concerning the role of females is [sic] detrimental to the children and the children are confused by the different religious teachings of the parties." Id. The court did not explain why the U.S. Constitution permitted it to judge Robert's religious beliefs detrimental. See note 136 supra.

163. See Lange, 502 N.W.2d at 145-46. Often courts choose one custodial parent to control the child's formal religious training, reasoning that the best interests of the child require noncontradictory religious education. See LeDoux v. LeDoux, 452 N.W.2d 1, 5 (Neb. 1990) (affirming custodial mother's right to control child's religious training, in part because father's religion posed immediate emotional harm to child); In re Marriage of Oswald, 847 P.2d 251 (Colo. Ct. App. 1993) (invalidating visitation award to paternal grandmother who wished to take child to her church because custodial parent has right to determine child's religious training). In Marjorie G. v. Stephen $G ., 592$ N.Y.S.2d 209 (Sup. Ct. 1992), the court affirmed its policy of noninterference in the child's upbringing absent a showing of harm, and acknowledged the right of the custodial mother to determine the child's religion. Id. at 210 . However, the court specifically permitted the father to include the children in his Jewish religious activities "as long as no attempt is made to indoctrinate the children with any purely theological or ideological dogmas, principles or beliefs that are unacceptable to the [mother's faith]." Id. at 212.

This opinion illustrates the inherent conflict in states where the custodial parent obtains exclusive control of the child's religious training. The court cannot restrict the noncustodial parent's Yoder right to teach the child his religion absent a substantial threat of or actual harm to the child resulting from the mixed religious training. Neither can the court interfere with the custodian's legislative or judicial right to control the religious training of the child. The two proscriptions are at odds and lead courts to issue confusing instructions such as the one in Marjorie G., which forces the father to assess the mother's religious principles in order to avoid contradicting them. See also S.E.L. v. J.W.W., 541 N.Y.S.2d 675, 679 (Fam. Ct. 1989) ("J.W. will be permitted to take Natalie to Jehovah's Witness services on Sunday but shall not involve her any further except that he may answer casual questions which she might ask him. No other exposure to Jehovah's Witness doctrine and activities will be permitted....").

Legislatures and courts need to address this dilemma. Using the NOAH procedure, courts would ignore religion when making the initial custody determination and allow both parents to provide the child with the religious training of his or her choice. If harm resulted from the mixed 
While we emphatically affirm Robert's [free exercise] right under the United States and Wisconsin Constitutions to hold and profess his religious beliefs, he cannot engage in conduct causing his children to reject the religion Elizabeth has chosen for their children. ...

... [The free exercise right] does not include the right to engage in religious conduct, such as proselytizing, that runs afoul of an otherwise valid law. ${ }^{164}$

The court relied on $S m i t h{ }^{165}$ to justify the Wisconsin law that gives major decisionmaking privileges to the custodial parent. ${ }^{166}$ The Oregon drug laws at issue in Smith were neutral laws that resulted in the prohibition of religious use of peyote. Just as these laws were otherwise valid, so the Wisconsin law was a valid, neutral law that prohibited Robert from sharing in the religious indoctrination of his children. ${ }^{167}$ The irony is that the Wisconsin appellate court never even mentioned Wisconsin v. Yoder.

\section{B. The Results of a Constitutionality Review of Recent Custody Cases}

The cases represented in Group 1 -actual harm cases-required that parental practices actually harm children before the state interfered with a Yoder right in making a custody determination. Group 2's substantial threat cases reflect the Yoder test. Cases from Group 3-risk cases-and cases from Group 4-relevant issue cases-do not meet the Yoder test. Courts required less than a "substantial threat" of harm before they allowed religious practices and beliefs to influence custody determinations. These determinations from Groups 3 and 4, therefore, violate the Free Exercise Clause and unconstitutionally abridge the parental right to religious freedom. Thus,

training, the parties could seek court intervention and the court would be justified in restricting the parents' practices. For a discussion of the effects of mixed religious training, see note 233 infra.

164. Lange, 502 N.W.2d at $147-48$ (citations omitted). The court explained that its restriction did not prevent Robert from discussing religion with his children. He simply could not "impose" his religious views nor cause them to reject their mother's religion. Id. at 147. This is a doubtful distinction since Robert could not obtain unsupervised visits until he proved he would not "impose" his religious views on the children. It appears quite plausible that the effect of this restriction was to silence him completely, if he wanted to earn unsupervised visitation with his children.

165. Employment Div., Dep't of Human Resources v. Smith, 494 U.S. 872 (1990).

166. See Lange, 502 N.W.2d at 148.

167. See id. at 148-49. In his dissent, Justice Dykman reminded the majority that Smith distinguished cases, including Yoder, that involved the combination of free exercise rights with other fundamental rights. Id. at 150; see also City of Boerne v. Flores, 117 S. Ct. 2157 (1997) (striking down the Religious Freedom Restoration Act, noting that it extended beyond the free exercise of religion). In the majority opinion, Justice Gartzke responded to this point by saying that the Lange's was not a hybrid situation like Yoder in that Robert lost the parental right to choose his children's religion when he lost custody. See Lange, 502 N.W.2d at 148-49. This argument begs the question. Robert may have lost custody due to his religious beliefs in violation of his First Amendment rights. The laws that deprived him of his Yoder rights may not have been neutrally applied. 
sixteen of fifty-three cases (30\%) were arguably decided in violation of the Constitution.

The losing parents in the cases in Groups 3 and 4 lost more than their Yoder rights; they may have also lost custody and other attendant nonreligious rights. When a court fails to apply a constitutional threshold test before considering parental religious practices or beliefs, it also risks depriving a deserving parent of full parental rights to care for and nurture his or her child.

Even those courts in Group 2 that applied the substantial threat test may have violated parents' right to be free from religious discrimination and state interference with religious beliefs and practices. Palmore v. Sidoti ${ }^{168}$ arose in a similar context, involving race discrimination in child custody determinations. In that case, the Supreme Court held that uncertain or hypothetical harm was insufficient to justify interference with a parent's right to marry someone of another race. The Palmore Court refused to permit the "hypothetical effects of private racial prejudice"169 to influence a custody determination, rejecting the idea of "possible injury" stemming from racial bias. ${ }^{170}$ Therefore, the Court refused to sanction the custody court's consideration of the race of a custodian or her partner, and thus, in so doing, refused to endorse racial prejudice by giving effect to private biases. ${ }^{171}$

When religious practices pose a threat of harm, even a "substantial threat," the harm, like the potential for harm in Palmore, is hypothetical but not actual. If family law courts adopted the same standard for considering religious practices as the Palmore Court adopted for racial bias, then all of the substantial threat cases would have to be reconsidered because many of those courts endorsed religious discrimination by giving effect to the hypothetical threat of harm posed by one parent's religious practices. Palmore refused to consider race absent a showing of actual harm. If one extended this reasoning to consideration of religion then only $41 \%$ of the surveyed cases-the actual harm cases-employed an appropriate standard for considering parental free exercise rights. Moreover, that no case discussed and implemented the endorsement test suggests widespread disregard of Establishment Clause rights.

168. 466 U.S. 429 (1983).

169. Id. at 433 (quoting Palmer v. Thompson, 403 U.S. 217, 260-61 (1971) (White, J., dissenting)).

170. See id.

171. See id. ("Private biases may be outside the reach of the law, but the law cannot, directly or indirectly, give them effect."). 


\section{THE NOAH SOLUTION}

I propose a uniform procedure that would address the problems discussed above. The "New Osier-Actual Harm" (NOAH) procedure combines the stricter review of the actual harm standard with the process suggested by the court in Osier $v$. Osier. ${ }^{172} \mathrm{NOAH}$ resolves the key problems encountered by family courts considering religion. It protects each parent's right to the free exercise of religion and avoids the impression that a court endorses one religion over another or no religion, while still safeguarding children from actual harm caused by their parents' religious practices.

In Osier, the court suggested that a "divorce court should make a preliminary determination of the child's best interest, without giving any consideration to either parent's religious practices."173 If the court, for nonreligious reasons, initially resolves the custody dispute by choosing the parent with uncontroversial religious practices, the process ends after this bestinterests analysis. If, however, the losing parent protests the initial custody award based on the winning parent's religious practices, the court may proceed to the second phase of a bifurcated proceeding. The court may then evaluate the consequential impact of those religious practices, to determine whether they pose a threat of actual harm to the child.

During the second phase, "the court must make a threshold factual determination that the child's temporal well-being is immediately and substantially endangered by the religious practice." 174 If the religious practices do not so endanger the child, the second phase analysis ends and the custodial determination remains unchanged.

If, however, the court finds that the religious practices do substantially endanger the child, the court must balance the conflicting interests and modify the original determination to achieve "the least possible infringement upon the parent's liberty interests consistent with the child's well-being."175 The Osier court also required the trial court to make "specific findings of fact" on the basis of record evidence to support its decision. 176

NOAH differs from the Osier procedure in the standard of harm to be applied. The Osier court relied on a substantial threat test for the evaluation of the religious practices. However, Palmore ${ }^{177}$ suggests that this standard is not strict enough to avoid impermissible religious discrimination. What the Palmore Court explained about racial discrimination is equally applicable to religious discrimination: "[A] core purpose of the Fourteenth Amendment

172. 410 A.2d 1027 (Me. 1980).

173. Id. at 1029.

174. Id. at 1030.

175. Id.

176. Id.

177. Palmore v. Sidoti, 466 U.S. 429 (1984). 
was to do away with all governmentally imposed discrimination based on race. Classifying persons according to their race is more likely to reflect racial prejudice than legitimate public concerns ...."178

Extending this equal protection argument from race to religion in custody cases is both logically consistent and doctrinally necessary. Just as the Establishment Clause prevents government endorsement and inhibition of religion, the Equal Protection Clause ${ }^{179}$ mandates equal treatment of all persons similarly situated. In his concurring opinion in Kiryas Joel, ${ }^{180}$ Justice Kennedy compared the two clauses:

[T] he Establishment Clause forbids the government to use religion as a linedrawing criterion. In this respect, the Establishment Clause mirrors the Equal Protection Clause. Just as the government may not segregate people on account of their race, so too it may not segregate on the basis of religion. The danger of stigma and stirred animosities is no less acute for religious line-drawing than for racial. ${ }^{181}$

Justice O'Connor endorsed this reasoning. In her concurring opinion, she affirmed that "[a]bsent the most unusual circumstances, one's religion ought not affect one's legal rights or duties or benefits."182 Thus, a failure to extend Palmore could implicate serious equal protection issues. ${ }^{183}$

178. Id. at 432 (citations omitted).

179. The Equal Protection Clause provides that no state shall "deny to any person within its jurisdiction the equal protection of the laws." U.S. CONST. amend. XIV, $\$ 1$.

180. Board of Educ. of Kiryas Joel Sch. Dist. v. Grumet, 512 U.S. 687 (1994).

181. Id. at 728 (Kennedy, J., concurring).

182. Id. at 715 (O'Connor, J., concurring).

183. One might argue that Palmore is not pertinent to child custody cases. In Palmore, bigoted third persons, and not the African American stepfather, posed the hypothetical risk of harm to the child. If the Court had denied custody to the Caucasian mother, the Court would have given effect to harmful prejudice. The religion cases may appear different because the behavior of a parent poses a substantial threat of harm to the child.

Palmore is apropos for two reasons, however. First, many of the custody cases involving religion involve a threat of harm more like that described in Palmore than may be initially apparent. For example, in Pater, the father expressed the concem that the child would "be socially ostracized" because the mother, a Jehovah's Witness, prevented the child from celebrating birthdays and holidays, saluting the flag, and socializing with non-Witnesses. See Pater v. Pater, 588 N.E.2d 794, 799 (Ohio 1992). The mother's behaviors themselves were not harmful to the child. Only the social disapproval of and prejudice against the mother's dictates would have harmed the child. Had the Pater court denied the mother custody, it would have given effect to the popular bias against the practices of Jehovah's Witnesses. Thus, the potential harm in Pater was very much like the hypothetical harm rejected in Palmore.

Second, the precedential value of Palmore lies not in who posed the threat of harm to the child but in what, if anything, justified racial classifications. Recognizing that a fear of harm from private prejudice motivated the lower court decision, the Court refused to surrender to that fear and give effect to prejudice. See Palmore, 466 U.S. at 430-31. In the custody cases involving religion and no actual harm to the child, fear of harm from the free exercise of religion justifies classifications in the substantial threat cases. A court that surrenders to this fear gives effect to the inhibition of religious free exercise. At the very least, a court risks the appearance of inhibiting religion and violation of the Establishment Clause. Palmore stands for the proposition that fear of hypothetical 
The Constitution should have no more tolerance for religious discrimination in the guise of best interest determinations than it does for racially motivated justifications. Substantial risk of harm was sufficient to protect the uncontested religious rights of the Amish in Yoder, ${ }^{184}$ but actual harm should be required where a court must choose between competing religious views, in order to avoid discrimination and Establishment Clause violations. Hypothetical harm is constitutionally insufficient. Application of the actual harm standard, currently used in many states and seen in $41 \%$ of the surveyed cases, not only complements Palmore, it helps prevent religious bias by restricting judicial discretion.

Application of the NOAH procedure and the exclusion of all discussion of religious beliefs and practices during the initial phase is not a complicated task. ${ }^{185}$ Courts retain the discretion they require to resolve difficult custody issues, including the ability to determine the degree of harm stemming from a parent's religious practices and whether to fashion restrictions on those practices where the child is involved. ${ }^{186}$ Under NOAH, however, these elements are kept separate and identifiable.

Where the court has made the initial custody determination, without considering religion, the custodial parent controls the formal religious education of the child. ${ }^{187}$ The noncustodial parent retains his or her right to inculcate religious beliefs in the child. ${ }^{188}$ Only upon a modification request and a showing of actual harm from the mixed religious training could the court restrict the parent's religious inculcation practices, using the least restrictive means possible. Alternatively, if a mature child asserts a religious identity contrary to that of both parents, the court would accommodate the child's

harm cannot justify classifications based on race or creed, and provides valuable guidance on this point.

184. See text accompanying notes 26-34 supra.

185. The NOAH procedure also provides guidance where there is no initial determination of custody. For example, if a party requests a change of custody, the court would apply any relevant standards for modifications, such as a material change of circumstances, and then apply the NOAH analysis.

186. See, e.g., Kendall v. Kendall, 687 N.E.2d 1228, 1232-33 (Mass. 1997), petition for cert. filed, 66 U.S.L.W. 3422 (U.S. Apr. 27, 1998) (No. 97-1756) ("Other states have struggled to define what constitutes substantial harm. ... We adhere to the line of cases requiring clear evidence of substantial harm.").

187. Allowing the custodial parent to select the child's religion is completely consistent with the laws of many states. See, e.g., Lange v. Lange, 502 N.W.2d 143, 146 (Wis. Ct. App. 1993) (quoting Wisconsin statutes granting custodial parents the power to make "major decisions" for the child, including "decisions regarding ... choice of school and religion").

188. Although Yoder did not address custody, it did affirm parents' rights in general to decide the religious education of their children. See Wisconsin v. Yoder, 406 U.S. 205 (1972). But see note 163 supra (discussing conflicts that arise when one parent controls religious training); text accompanying notes 226-258 infra (demonstrating application of NOAH to mixed-training cases). 
free exercise right only upon a showing that a failure to do so would actually harm the child. ${ }^{189}$

Where the parents share joint custody but fail to agree on the selection of a parochial school, under NOAH the court would refuse to hear evidence concerning the schools' religious affiliations. Instead, if a choice of school were the issue, the court would employ the best interests standard, ignoring the religious affiliations of the particular educational institutions. Thus, the court would consider factors such as academic reputation, state accreditation, and athletic and arts programs. Only upon a showing of actual harm to the child would the court consider the school's religious affiliation.

One could argue that the NOAH procedure might increase the perception of bias since findings and possible modification orders would be explicitly based on religious practices. However, the requirement that the losing parent satisfy the actual harm standard provides the key safeguard. During the second phase, the court would employ a strict scrutiny analysis requiring a compelling state interest in the children's health and safety before infringing upon the parents' religious freedom. Because the actual harm test would be employed, and because only the least restrictive means would be used to satisfy the state's compelling interest, the court could justify impinging on a parent's First Amendment rights, if that were unavoidable.

The existing best interests standard will work more effectively by adding NOAH's "negative rule," which prevents court consideration of religion absent actual harm. The NOAH procedure better serves a child's best interests by safeguarding against religious discrimination that sometimes prevents the more qualified parent from receiving custody. Thus, to return to the original Pater $v$. Pater example, ${ }^{190}$ the NOAH procedure would have prevented the trial court from even considering Jennifer Pater's benign religious practices.

189. The Zummo court held that constitutional law prevented courts from determining the religious identity of children. See Zummo v. Zummo, 574 A.2d 1130, 1149-50 (Pa. Super. Ct. 1990). Only when children themselves assert a religious identity, having "reached sufficient maturity and intellectual development to understand the significance of such an assertion," can a court consider the religious identity of the child. Id. at 1149. The court opined that no uniform age conclusively evidenced maturity but estimated that children twelve or older would demonstrate such maturity; children younger than eight could not form such a religious identity. See id. What the Zummo court would do with information concerning the religious identity of a child remains unclear, since the issue was not reached because the Zummo children were too young to have developed religious identities. Presumably, the court would consider the child's asserted identity as a preference to be with the parent that would foster, or at least not stifle, that religious identity. Any other consideration might lead to the problem of court endorsement of that parent's religion.

None of the cases surveyed involved children who challenged the rights of a parent to determine their religious training. The Zummo court contemplated such an event, however, and suggested that U.S. Supreme Court precedent strongly indicated that the Court would honor the parental prerogative to control the religious indoctrination of the child. See id. at 1149-50 (citing Yoder, 406 U.S. at 231-32; Parham v. J.R., 442 U.S. 584, 603-04 (1979) (rejecting analogous claim by child concerning medical treatment)).

190. See text accompanying notes 1-4 supra. 
From the outset of the proceedings, Bobby Pater could have remained with his mother, his primary caregiver since birth.

In judicial determinations of custody, the NOAH procedure provides the guidance that courts desperately need in choosing between potential custodians with competing religious views. NOAH requires courts to focus first on the temporal well-being of children. Without this rule, court consideration of religion threatens both the constitutional rights of parents and the best interests of their children.

\section{APPLICATION OF THE NOAH PROCEDURE IN PARTICULAR CUSTODY CASES}

By applying the NOAH procedure to actual cases decided using other standards, one learns how the resulting custody determinations would differ and be improved. My survey of over fifty recent child custody cases revealed four common fact patterns or themes of dispute ${ }^{191}$ that will help analyze how NOAH improves the adjudication of these cases. They are: (1) relevant issue cases in which the court impermissibly considers the parent's religion as one factor in the best interests determination, (2) child abuse and medical cases, (3) religious training disputes in which the alleged harm is often not obvious and is not supported by verifiable evidence, and (4) relocation cases that implicate important policy issues.

\section{A. The Relevant Issue Cases and Religious Discrimination}

The efficacy of the NOAH standard in preventing the unconstitutional violation of Free Exercise rights appears most readily when NOAH is applied in cases previously decided using the relevant issue standard. In these cases, the potential for discrimination was blatant and often realized. ${ }^{192}$ This discrimination resulted when the court directly examined the parents' religions during its determination of the child's best interests; under this standard, religion is a permissible "relevant issue" like residence location and parental bonding.

In the Texas case of Alaniz v. Alaniz, ${ }^{193}$ the lower court permitted the jury to consider the parents' religions in a custody dispute. The mother, a Jehovah's Witness, appealed the jury's award of custody to the father, a Ro-

191. Note that these categories are not the same as those discussed above, see Part II supra, which relate to the different standards the courts used to determine custody.

192. While outright religious discrimination appears most dramatically in the context of the relevant issue cases, religious bias surfaces in all four groups.

193. 867 S.W.2d 54 (Tex. Ct. App. 1993). 
man Catholic. ${ }^{194}$ The appellate court noted that both parents "were conscientious and loving." 195 It considered whether the trial court had properly instructed the jury regarding the parties' constitutional rights and the appropriate standard for considering their religious affiliations. The appellate court found reversible error and concluded:

The jury should have known that the [mother's] beliefs which the jury might have considered unusual were not grounds for depriving her from being named managing conservator unless they [sic] concluded that her beliefs, teachings, or practices were illegal, immoral, or would be harmful to the children. ... We conclude that what is immoral or harmful should be left to the jury to apply community standards. What one jury might consider immoral, i.e. gambling, playing a lottery, drinking to excess, homosexual conduct, or abortion,- -another jury might not. 196

Even though the court remanded this case based on an impermissible evaluation of the mother's religion, the standard set by the court of appeals still highlights several problems that NOAH would prevent. First, the Texas appellate court still permitted the jurors to judge a parent's religious beliefs immoral. Such license to equate immorality with actual harm gives legal weight to disapproval of a minority religion that may not attract "moral" approval in the local community. Moreover, equating immorality with actual harm obfuscates the threshold level of harm required before the state can deprive a parent of custody. Purportedly immoral beliefs might have absolutely no negative impact on a child, let alone rise to the level of actual harm. ${ }^{197}$

Second, if jurors find those heart-felt religious beliefs immoral, the parent can lose custody. Third, it allows popular community opinion to displace the United States Constitution. Fourth, this Texas standard sanctions the deprivation of parental rights when a parent exercises other constitutionally protected rights, such as the right to abortion. ${ }^{198}$ Finally, permitting juries to decide custody invites even greater inconsistency. What one jury considers immoral another may not. If a judge denied custody to a Jehovah's Witness because her faith was "immoral," an appellate court could reverse. The

194. See id. at 54-55. Texas allows a jury to decide a child custody matter. See TEX. FAM. CODE ANN. $\$ 105.002$ (West 1996) (providing that a party to a family law dispute may request a jury, except in adoption cases).

195. Alaniz, 867 S.W.2d at 55.

196. Id. at 57 (footnote omitted). In a footnote, the court cautioned that judges should exclude attacks upon a party's theology. See id. at 57 n.3.

197. For discussions concerning the inquiry into religious beliefs versus the inquiry into harmful practices, see note 162 supra; note 259 infra; text accompanying notes $155-156$ supra.

198. The Supreme Court has made it clear that local mores cannot circumscribe constitutional liberties, no matter how locally unpopular the exercise of those right may be. See Planned Parenthood v. Casey, 505 U.S. 833 (1992) (redefining but upholding the right to abortion); Roe v. Wade, 410 U.S. 113 (1973) (finding a protected right to abortion that is beyond the purview of state criminal statutes). 
Texas rule, in combination with its jury system, affords unconstrained opportunity for religious bias. Not only do members of minority religions suffer under this system, but the best interests of the children can be obscured by hostility toward their parents' religious beliefs.

If the NOAH procedure had been applied in Alaniz, the jury would not have heard evidence concerning the mother's Jehovah's Witness faith until after the initial custody determination. If the father had been awarded custody, the mother could not have claimed discrimination since her religion would never have been considered. If the mother had been named managing conservator in the first phase, the father could have raised the issue of the mother's religion for consideration in the second phase. Only by submitting evidence that the mother's behaviors were actually harming or would actually harm the children could the father have then obtained a modification of the initial determination.

Application of the NOAH procedure would have significantly reduced the opportunity for and appearance of religious bias. During phase one of the NOAH procedure, the best interest of the child, rather than the morality of the mother's beliefs, would have received more focused attention. When distracted by unfamiliar religious beliefs and practices, and the expression of religious bias by witnesses or litigants and their counsel, jurors cannot devote their full attention to the child's needs and to who best meets those needs.

Moreover, the NOAH procedure might have streamlined the process, avoiding appeals and repeat jury trials, conserving the time and assets of both the courts and the parties. Finally, application of the NOAH procedure would make for much more internally consistent law in jurisdictions that use juries in custody cases, because the juries would not be continually evaluating the morality of the religious beliefs and practices of minority religions and potential custodians.

Similar to Texas law, Mississippi law permits a court to reject parents whose religious practices it deems immoral. ${ }^{199}$ In Muhammad $v$. Muhammad, ${ }^{200}$ a father belonging to the New Nation of Islam appealed a dissolution decree that awarded custody to the mother. ${ }^{201}$ Before the Mississippi Supreme Court, he argued, in part, that the chancellor below had im-

199. See Harris v. Harris, 343 So. 2d 762, 764 (Miss. 1977) (noting that courts may consider immoral practices); see also text accompanying note 196 supra. In Harris, the court overturned the disqualification of a snake handling fundamentalist mother, stating that "[ $t]$ he chancery court had no authority to dictate to Mrs. Harris what religion she should teach her child so long as it did not involve exposing him ... to what society in general deems immoral practices." Id. In part because snake handling presumably fails to constitute an immoral practice, the appellate court reversed the decision depriving Mrs. Harris of custody. $I d$.

200. 622 So. 2d 1239 (Miss. 1993).

201. The case arose from the father's suing for custody, with a cross complaint from the mother suing for divorce and custody "on the ground of habitual cruel and inhuman treatment." Id. at 1240. A chancellor found for the mother. See id. at 1241. 
properly disparaged his religion. The supreme court gave a lengthy description of the father's Black Muslim beliefs and practices, quoted long portions of the trial transcript, ${ }^{202}$ and concluded:

The chancellor did engage in inappropriate judicial conduct with his sua sponte interjection of personal opinion. This served, however, only to expose a view held by the chancellor that in ordinary circumstances would be present but tacit. ... The record simply does not support the contention that the chancellor's views so overwhelmed his reason that his decision on the issues cannot be accorded the same degree of respect as is ordinarily enjoyed by the findings of a trial court. Where the parties have competing religious views it is impossible to have both views represented by a single jurist. This is especially true where, as here, religious doctrine embrace [sic] a negative view about a particular race [Caucasian]. As to this basis for reversal, we can say with confidence that the chancellor should be affirmed. 203

This passage betrays the supreme court's own bias. After listing a number of the father's beliefs and behaviors that many Americans, especially American women, might find offensive, the supreme court used sympathy to excuse clear bias on the part of the lower court. Because the chancellor was open about his bias, somehow the effects of that bias were excusable.

The supreme court implied that the father's racist religious views justified the trial judge's hostility, or at least the judge's inability to represent the religious viewpoints of all parties. A judge need not represent the religious views of any party, however. Moreover, the First Amendment bars open disapproval and inhibition of religious beliefs. The dissent lamented the chancellor's remarks: "His displeasure with the teachings and tenets of this religious group [Black Muslim] was obvious," noting that "[a]lthough I would

202. The supreme court described in detail the way the family lived, emphasizing how the mother and child were treated in the New Nation of Islam community called "the University":

Virtually every aspect of life of the University is impacted by religious doctrine. The social and family structure is strongly patemal. Men are viewed as the maintainers of their wives and children. Women are required to submit to their husbands. The role of the woman is viewed primarily as being the helpmate of her husband. Child care is one of her chief responsibilities. Women make no decisions. They cannot leave the confines of the community without the permission of their husband. Members of the faith are not allowed to ingest alcohol, tobacco, drugs or other intoxicating substances. Neither are they allowed to eat red meat. Although the food supply is adequate in quantity, the diet at the University is fairly limited to beans, broccoli, fish, bread, cauliflower, and sometimes corn. Meals are restricted to one per day for adults. Fasting from these meals periodically occurs. Women are required to breastfeed their children. At least some of the milk and juices received by women through the Women, Infants and Children (WIC) program go [sic] to the operation of a bakery. Mail is subject to being censored.

$I d$. at 1242 . One wonders whether the inclusion of these facts, mingling a discussion of the father's religion with descriptions of how the mother and children lived, could have had any effect but to allow the supreme court to enforce its own biases against the religion as part of its custody decision. Perpetuating this mixed consideration on review did nothing to help the supreme court identify the impermissible biases, and permitted the initial unconstitutional endorsement of one religion over another.

203. Id. at 1248 (citation omitted). 
be reluctant to term the chancellor's behavior a violation of the constitutional right to religious freedom, his conduct cannot be discounted and undermines confidence in his determination of child custody."204

A central question left unanswered by this case is why no one addressed the Establishment Clause issue. Here the Lukumi case, ${ }^{205}$ in which the U.S. Supreme Court invalidated an apparently neutral law that made Santería animal sacrifice illegal, provides guidance on this issue. The Lukumi Court admonished: "The Free Exercise Clause commits government itself to religious tolerance, and upon even slight suspicion that proposals for state intervention stem from animosity to religion or distrust of its practices, all officials must pause to remember their own high duty to the Constitution and to the rights it secures." 206 This Supreme Court holding specifically abjures state intervention motivated by religious hostility.

In Muhammad, the chancellor's bias tainted his motivations. Hostile to Black Muslims, as the City of Hialeah was to Santeria adherents, the chancellor intervened and disqualified the father from becoming custodian of his children. To determine that the chancellor's comments violated the Establishment Clause, the Mississippi Supreme Court, an objective observer, could have applied either the Lemon test ${ }^{207}$ or the O'Connor endorsement test. ${ }^{208}$ Either way, the chancellor's comments amount to clear judicial disapproval of the father's faith. The custody award to the mother reinforced the appearance of bias. Had the court acknowledged the Establishment Clause issue, it would have lessened the appearance of bias, even if other interests had supported awarding the mother custody.

The application of the NOAH test in cases involving generally unpopular faiths and people with politically incorrect practices might appear to lead to equally unpopular decisions, if it allows the parent with controversial practices to obtain custody. But NOAH is a procedural provision, not a substantive one. It protects the constitutional religious interests of the parents, but leaves intact the secular portions of traditional best interests analysis. Through the use of the actual harm standard, children are still protected against injury arising from religious practices.

Applying NOAH to the Muhammad case provides a clear example of the difference such a procedure could make. With the NOAH rule the same court that denied custody to the Black Muslim father would be prohibited

204. Id. at 1252 (Smith, J., dissenting).

205. Church of the Lukumi Babalu Aye, Inc. v. Hialeah, 508 U.S. 520 (1993). See note 49 supra and accompanying text.

206. Lukumi, 508 U.S. at 547.

207. See text accompanying notes $75-78$ supra.

208. See text accompanying notes 79-89 supra. 
from considering the parties' religions until after it had made an initial determination of custody.

In the first phase, Mrs. Muhammad could present nonreligious evidence of the living conditions at the New Nation of Islam community, such as the "terrible overcrowding," 209 the unaccredited school, ${ }^{210}$ and the lack of food.211 Also in phase one, the father could present evidence that he abstained from tobacco, alcohol, and red meat, and that he loved and cared for his children. The phase one determination would reveal only the court's consideration of the children's best interests, and would not involve an unconstitutional consideration of religion.

If the court awarded Mrs. Muhammad custody in phase one, the father could appeal that decision in a second phase. In that phase, he could argue that his religion mandated fasting and a special school, and that he should not lose custody because of his free exercise of his religion. In this second phase, the court would consider whether the particular behaviors actually harmed the children. If the court were to determine that the deprivation of food and lack of accreditation did not harm the children, it could change its original decision to grant the mother custody with a memorandum of factual findings to support its change. The court could still find, however, that fasting and substandard schooling harmed the children, and affirm its phase one determination of custody.

Likewise, if the court awarded Mr. Muhammad custody in the first phase, the mother could raise the issue of his religious practices in a second phase. The court would have to evaluate whether the father's religious conduct actually harmed the children. In phase two, for example, a child psychologist who had examined the children might testify that the manner in which the father spoke to and treated women and Caucasians caused the children to have nightmares or withdraw emotionally. ${ }^{212}$ Alternatively, one could imagine that Mr. Muhammad's practices did not actually harm the children, but merely encouraged unpopular attitudes. If the court found, based on proffered evidence, that the father's religiously motivated sexist and racist attitudes resulted in behaviors that actually harmed the children, the court could change its phase one determination, and grant custody to the mother.

Depending on the facts available, the court might determine, in phase two, that Mr. Muhammad's conduct was so harmful that the father should receive only restricted visitation rights. The court would have to justify such

209. Muhammad, 622 So. $2 \mathrm{~d}$ at 1247.

210. See id.

211. See id. at 1248.

212. Cf. Lange v. Lange, 502 N.W.2d 143, 145 (Wis. Ct. App. 1993) (finding "religious beliefs concerning the role of females ... detrimental to the children"). 
a dramatic change from its phase one determination, however, with detailed findings of fact that clarified why the proposed modification was the least restrictive alternative. Alternatively, the court might decide that an order enjoining the specific harmful conduct would be the least restrictive modification available.

This discussion of NOAH and Muhammad demonstrates several points. First, under NOAH, a man with socially unpopular religious attitudes, one who condones the subjugation of women, could potentially receive custody. If he were a better caregiver, however, and if his unpopular religious practices did not actually harm the child, this would be the correct result. Second, the Muhammad trial court could have addressed most of the potentially objectionable behaviors during the initial phase of the NOAH procedure, thus preventing the infusion of the chancellor's religious bias. This analysis of harmful behaviors involves nothing new for actual harm courts. The NOAH analysis simply occurs after the initial custody determination, to ensure that religious bias does not cloud the pure determination of caregiving skills, and mandates a finding of fact to justify a modification.

Admittedly, the NOAH procedure has its limitations. A court sharing the religious views of Mr. Muhammad would be unlikely to find actual harm resulting from the practices in question. Harm, particularly psychological harm, is likely to be viewed through a lens tinted by the jurist's religious views. By limiting the opportunity for the exercise of discretion to a bifurcated proceeding and requiring actual harm, however, NOAH minimizes the opportunity for the exercise of religious bias while still protecting children from actual harm.

\section{B. Child Abuse and Medical Cases}

Cases that either contain proven allegations of child abuse or concern a parent's withholding of medical treatment from the children comprise a second subset of cases. In these cases, one parent typically complains of religious discrimination or asserts a free exercise right to support either their corporal punishment of their children or their decision to refuse the children needed medical care.

Courts at present appropriately conclude that the First Amendment does not sanction child abuse. ${ }^{213}$ Peterson $v$. Peterson ${ }^{214}$ provides an example of a

213. These cases present less difficulty to the courts because actual harm is usually clear and often the claimed religion does not require corporal punishment. See, e.g., Jakab v. Jakab, 664 A.2d 261, 265 (Vt. 1995) (finding that the record did not show that being a Jehovah's Witness required the father to physically discipline his children by beating them); Varnum v. Varnum, 586 A.2d 1107,1112 (Vt. 1990) (affirming that the lower court's custody decision was based primarily on the mother's abuse, which went beyond what her Jehovah's Witness religion required). Of course, courts are not always so consistent in considering the danger of physical harm. See, e.g., Leppert v. 
court's use of the substantial threat test in a case involving abusive behavior. Robert Peterson filed for a modification of a decree that.had granted custody to the mother, Carol Peterson. The record showed that Carol had given one child over 40 lashings with a leather belt. ${ }^{215}$ The trial court granted the modification, giving custody to Robert. It enjoined Carol from physically punishing the children and from speaking to them at all about her religion under penalty of contempt. . $^{216}$

The appellate court found that Carol's proven abusive behavior constituted a material change of circumstances and affirmed the modification order. It concluded that: (1) "excessive use of corporal punishment poses an immediate and substantial threat" of harm to the children;217 and (2) the trial court abused its discretion in finding that Carol's religious beliefs, rather than her practices, undermined her ability to perform parenting functions. ${ }^{218}$ Instead of prohibiting Carol from speaking about her religion, the appellate court enjoined her from contradicting, disparaging or questioning the validity of the father's religion. ${ }^{219}$

The Peterson modification case illustrates how the NOAH test could work in the child abuse fact pattern. During the initial phase of the modification proceeding, Robert would present evidence of the beatings. If Carol retained custody, the inquiry would end without mention of Carol's religion. If, however, the court transferred custody to Robert, it could obviate the need for a phase two analysis by finding that the beatings harmed the children. Then, Carol would have no reason to pursue the matter. Because the beatings would have already been found harmful, she could anticipate the futility of arguing that her religion compels corporal punishment.

If, during the initial phase, the court transferred custody to Robert but failed to label the beatings as actually harmful, Carol might pursue a phase two analysis. She would argue that her religion mandated the use of corporeal punishment. Upon a finding of actual harm to the children, the court could justify its transfer of custody to Robert and narrowly tailor any restrictions on Carol, as was actually done. Alternately, under NOAH the court might determine that Carol was the more appropriate parent, but for the physical abuse, and leave Carol with custody with the restriction that she not physically discipline the children. Such an order, leaving custody with a

Leppert, 519 N.W.2d 287, 289-90 (N.D. 1994) (reversing a custody award to transfer children to their father, citing the "extreme danger to the children, both physically and emotionally" resulting from the mother's beliefs, but noting the lack of actual abuse).

214. 474 N.W.2d 862 (Neb. 1991).

215. See id. at 865-66.

216. See id. at 872 .

217. Id. at $869-70$.

218. See id.

219. See id. at 872. 
parent who previously beat her children, might be unpopular. But if the court could ensure that Carol would desist from corporal punishment, and if it determined that Carol was the preferred custodian otherwise, such an arrangement might serve the best interests of the children.

Of course, Carol's proven abusive behavior in the Petersen case left no room for speculation and facilitated the court's decision. One can envision a scenario, however, in which a parent states an intent to engage in a practice that others might find abusive, but which, standing alone, does not threaten physical harm. Does the NOAH standard, with its actual harm requirement, still safeguard a child? The problem of safeguarding children in the custody of a parent who might refuse needed medical care provides a useful vehicle for exploring this question.

In Garrett v. Garrett, ${ }^{220}$ the court applied the substantial threat test where the mother, a Jehovah's Witness, admitted that she would refuse to permit any of her children to receive a blood transfusion. ${ }^{221}$ The appellate court affirmed the custody award to the mother, and concluded that the father's objection, based solely on the mother's religion, must fail because the "record is devoid of any expert testimony that Jeanne's religious practices are imminently harmful to the children."222

In response to the blood transfusion testimony, the appellate court held that:

[N]o evidence was presented showing that any of the minor children were prone to accidents or were plagued with any sort of affliction that might necessitate a blood transfusion in the near future. We cannot decide this case based on some hypothetical future accident or illness which might necessitate such treatment. Facts such as the statistical frequency of blood transfusions for normal children and the degree of risk involved in taking or refusing blood or chemical substitutes must be proved by proper evidence, like any other facts. ${ }^{223}$

Courts applying the actual harm standard have also found that speculation about the need for medical attention did not justify the denial of custody. 224

Application of the NOAH standard would lead to the same result, while providing greater procedural safeguards. Absent evidence that religious beliefs regarding medical treatment would inevitably harm a child, a parent could not be denied custody. Perhaps in phase two, however, the NOAH court would consider restricting the custodial parent such that if the need for emergency medical decisions arose, and if the harm of a religious/medical

220. 527 N.W.2d 213 (Neb. Ct. App. 1995).

221. See id. 220-21.

222. Id. at 221; see also In re Marriage of Wang, 896 P.2d 450, 450-51 (Mont. 1995) (holding that lack of findings on father's unconventional religion does not defeat custodial award to him).

223. Garrett, 527 N.W.2d at 221 (citations omitted).

224. See, e.g., note 133 supra. 
belief becomes a certainty, the noncustodial parent would gain the right to make those decisions. 225

Faced with a child with a serious medical condition, a NOAH judge might rule that a parent with religious beliefs that prohibit medical treatment cannot adequately care for a child. This ruling would amount to a finding of actual harm. Moreover, a NOAH court would not need to delve into the parent's religious beliefs to deal with this situation. Once apprised of the child's medical needs in the first phase of the court proceeding, the court could pose the question, "Will you arrange for the child to receive medical care?" A negative answer from a potential custodian would disqualify the parent without necessitating an investigation into the parent's beliefs.

The losing parent might request a phase two analysis of her free exercise rights. The judge would then make detailed findings of fact, supported by evidence, that the parent's religious proscriptions regarding medical care would harm the child. Obviously, the NOAH procedure will often produce the same results as the current system. The NOAH procedure ensures against religious bias corrupting the system. It may also result in fewer First Amendment appeals. Thus, the NOAH standard can safeguard the children and their medical needs while still protecting parental constitutional rights, and avoiding the appearance of disapproval of religious beliefs and practices.

\section{Religious Training and Visitation Restriction Cases ${ }^{226}$}

For most cases in which parents have differing religious views, religious training becomes an issue. In over $70 \%$ of the surveyed cases, parents argued about religious training and education. In many of these cases, one parent argued that mixed religious training or exposure to conflicting religious views either harmed or posed a substantial threat of harm to the children. Unlike the child abuse and medical treatment cases in which harm was proven, the cases dealing with religious training or visitation are more like the "relevant issue" cases in that the alleged harm is arguable. These cases therefore highlight the differences between NOAH and conventional analysis, providing a good test of the efficacy of the NOAH procedure.

Many courts have addressed the advisability of exposing children to multiple religions. Some find mixed exposure harmful to children. ${ }^{227}$ Others

225. A written custody order would ensure compliance and would provide the noncustodial parent with documentation for health care providers. Obviously, the custodial parent could avoid this provision in a variety of ways. If the court suspected religious zeal might prompt noncompliance, the court could decline to order such an arrangement. See, e.g., Lange v. Lange, 502 N.W.2d 143, 145 (Wis. Ct. App. 1993) (refusing to fashion special orders, the court reasoned, "The respondent indicates he intends to follow God's order, not the court's.").

226. I place these issues together because deciding the child's religious training almost always includes a related restriction on one parent's custodial time allotment. 
do not presume that harm will result from mixed training. ${ }^{228}$ The Zummo case, discussed earlier, ${ }^{229}$ centered on the parents' disagreement concerning the children's religious training. The Zummo court rejected Pamela and David's "contract" concerning that training 230 and dismissed the notion that a mixed religious environment was necessarily detrimental to children. ${ }^{231}$ The court explained that "the speculative possibility of mere disquietude, disorientation, or confusion arising from exposure to 'contradictory' religions would be a patently insufficient 'emotional harm' to justify encroachment by the government upon constitutional parental and religious rights of parents, even in the context of divorce."232 The Zummo court continued:

It is well established that high levels of parental conflict before or after divorce are a significant factor in the distress experienced by children of divorce, regardless of the source or topic of the conflict. Thus, acrimonious disputes, or situations in which one parent uses religion as a tool to poison his or her children with disrespect for or animosity toward the other parent might present a compelling case for intervention between two Jews or two Christians of similar sects, while a respectful but irreconcilable dispute between and Christian and a Jew would not. ${ }^{233}$

The Zummo court also rejected the idea it had a duty to preserve religious stability in the child's life:

[T] he prohibition on preferring some religion to none, may not be avoided by suggesting that religion or religious stability is only being considered because of the secular rather than spiritual benefits expected to arise from protecting the stability of a child's religious beliefs .... The exclusion of the benefits of sta-

227. See, e.g., LeDoux v. LeDoux, 452 N.W.2d 1, 5 (Neb. 1990) (affirming trial court's determination that mixed religious training would negatively affect the children's well-being); Lange, 502 N.W.2d at 145 (quoting lower court's finding that children were "confused by the different religious teachings of the parties").

228. See, e.g., Zummo v. Zummo, 574 A.2d 1130, 1154-57 (Pa. Super. Ct. 1990) (discussing mixed religious training and concluding that it was not generally harmful to children); In re Marriage of Weiss, 49 Cal. Rptr. 2d 339, 345 (Ct. App.), cert. denied, 117 S. Ct. 509 (1996) (presuming no harm from mixed religious training).

229. See text accompanying notes 137-152 supra.

230. See Zummo, 574 A.2d at 1143-48.

231. See id. at 1154-57; see also In re Marriage of Moore 526 N.W.2d 335, 337-38 (Iowa Ct. App. 1994) (denying the father's request for a change of custody based on the claim that the religious training his children received with their mother alienated them from him).

232. Zummo, 574 A.2d at 1155 . For the opposing view, see Kirchner v. Caughey, 606 A.2d 257 (Md. 1992) (remanding to consider limiting noncustodial parent's religious training of child, in view of expert testimony regarding child's stress arising from conflicting training); Lebovich v. Wilson, 547 N.Y.S.2d 54 (App. Div. 1989) (evidence of actual, harmful stress on child caused by religious training conflict warranted curtailing her participation in her father's religion).

233. Zummo, 574 A.2d at 1156 (citations omitted); see also In re Marriage of Weiss, $49 \mathrm{Cal}$. Rptr. 2d 339, 345 (Ct. App.), cert. denied, 117 S. Ct. 509 (1996) (agreeing with Zummo explicitly that the harm to a child arising from conflicting training is more a result of parents' conduct than of theological difference); McCown v. McCown, 649 A.2d 418, 421, (N.J. Super. Ct. App. Div. 1994) (noting that differing religions do not impose unique harms independent of usual distress resulting from parents' divorce); note 136 supra. 
bility in religious inculcation and of religiosity in general are apparently part of the price which must be paid for religious freedom and constitutional recognition of parental rights. ${ }^{234}$

These passages reflect the court's commitment to avoiding the advancement of one religion or religion generally.

In contrast to Zummo stands LeDoux v. LeDoux. ${ }^{235}$ Edward LeDoux, a Jehovah's Witness, appealed a dissolution decree ordering him to refrain from exposing his children, including his son Andrew, to any religious practices or teachings inconsistent with Catholicism, the religion of his wife Diane. ${ }^{236}$ The Supreme Court of Rhode Island ruled that the trial court had not abused its discretion since Edward's practices were negatively impacting the children. The supreme court determined, "There is ample evidence to conclude that the stress Andrew was experiencing posed an immediate and substantial threat to his well-being."237

The evidence relied upon by the supreme court included Diane's testimony concerning her fights with Edward over their religious differences, his refusal to celebrate holidays, and his general hostility to Catholicism. A psychologist called by Diane testified that conflicts between the parents' religions contributed to Andrew's stress. 238 Citing Prince, the supreme court justified its decision to restrict Edward on the grounds that free exercise "does not include liberty to expose . . the child to ... ill health . ..."239 The supreme court also acknowledged Diane's right as the custodial parent to control the child's formal religious indoctrination. ${ }^{240}$

Justice Shanahan wrote a strong dissent. He proposed that noncustodial parents should not be blocked from exposing their children to their religious

234. Zummo, 574 A.2d at 1151-52; see also Boylan v. Boylan, 577 A.2d 218 (Pa. Super. Ct. 1990), overruled on other grounds by G.B. v. M.M.B. 670 A.2d 714 (Pa. Super. Ct. 1996) (rejecting appeal by father who claimed to have same religion as children but affirming that courts should consider parental religion in custody cases). But see Edwards v. Edwards, 829 S.W.2d 91, 93 (Mo. Ct. App. 1992) (using best interests test to support custody award to father when mother proved religiously unstable).

235. 452 N.W.2d 1 (Neb. 1990).

236. See id. at 2 . The court deemed its restriction narrowly tailored because it enjoined Edward from discussing only those aspects of the Jehovah's Witness faith that conflicted with his exwife's religion. See id. at 5 .

237. Id. at 5. But see Zummo, 574 A.2d at 1151-52 (deferring the issue of a child's religion to the parents).

238. See LeDoux, 452 N.W.2d at 3-4.

239. Id. at 486 (quoting Prince v. Massachusetts, 321 U.S. 158, 166-67 (1944)). In contrast to many of the surveyed child custody cases, the LeDoux court referred frequently to U.S. Supreme Court precedent.

240. See LeDoux, 452 N.W.2d at 5. LeDoux was not a modification case. The trial court had just chosen Diane as the custodial parent and then used that appointment to give her control of the children's formal religious training, which is standard practice in Nebraska. See also note 163 supra; $c f$. Burrows v. Brady, 605 A.2d 1312, 1316 (R.I. 1992) (holding that when parents have joint custody, both parents have an equal right to influence the religious beliefs of their children). 
beliefs absent a clear showing that their beliefs would harm the child,241 and then cautioned that a court should not assume or surmise harm. ${ }^{242}$ Additionally, he noted that the law "tolerates and even encourages up to a point the child's exposure to the religious influences of both parents although they are divided in their faiths."243 Justice Shanahan provided an exhaustive review of the "evidence" that motivated the majority opinion. The record revealed that Diane had harbored significant hostilities toward Edward's faith and that she had conveyed those hostilities to Andrew, telling him that Jehovah's Witnesses "would mess up his [Andrew's] mind just like they messed up the mind of his father."244 Furthermore, the psychologist testified "that with the cooperation of parents, a child might be introduced to two different religions in a manner which would not be stressful."245 Based on his review, Justice Shanahan could not conclude that Edward's religious practices would be harmful to the child. ${ }^{246}$

Justice Shanahan also expressed regret over the majority's extensive restriction of the father's expression of his religious views. The Justice wondered how the father could resolve the "countless quodlibets concerning the dichotomy of dogma between Jehovah's Witnesses and Catholicism"247 without violating the order. He added that the order "casts a judge in the role of a theological umpire."248

The LeDoux case exemplifies Zummo's admonition that "situations in which one parent uses religion as a tool to poison his or her children with

241. See LeDoux, 452 N.W.2d at 7 (Shanahan, J., dissenting).

242. See id. at 7-8.

243. Id. at 8 (quoting Felton v. Felton, 418 N.E.2d 606, 607-08 (Mass. 1981)).

244. Id. at 8 (quoting the record). $C f$. Bienenfeld v. Bennett-White, 605 A.2d 172, 182 (Md. Ct. Spec. App. 1992) (affirming change of custody to father, reasoning that when the mother's religious views pose a threat to the children's relationship to their father, her views impact the children's emotional well-being).

245. LeDoux, 452 N.W.2d at 10 (Shanahan, J., dissenting).

246. See id; cf. In re Marriage of Jensen-Branch, 899 P.2d 803, 805 (Wash. Ct. App. 1995) (noting that the issue of religious decisionmaking merited further evaluation). Jensen-Branch illustrates the need for clear and convincing evidence of harm caused by religion. In this case, the noncustodial father appealed restrictions that enjoined him from giving his children religious education in the Worldwide Church of God. It affirmed that a trial court could consider the parents' religious affiliations but noted that "there must be a substantial showing of actual or potential harm to the children from exposure to the parents' conflicting religious beliefs." Id. at 808 . The court added:

Thus, findings of actual or potential harm must be made with reference to specific evidence and the specific needs of the children involved, as opposed to general findings of harm which leave an appellate court searching the record for evidence that may or may not have been seen as pivotal or relevant by the trial court.

Id. at 808-09. The court concluded that insufficient evidence supported the trial court's ruling and remanded the case for further proceedings. But see note 222 supra.

247. LeDoux, 452 N.W.2d at 11.

248. Id. 
disrespect for or animosity toward the other parent might present a compelling case for intervention."249

Just two months after LeDoux, Justice Shanahan wrote the majority opinion in Von Tersch $v$. Von Tersch. ${ }^{250}$ Geri Von Tersch, the custodial parent, appealed a custody order that required her to remove her children from religious school and enroll them in public school. Geri argued that the order unreasonably interfered with her First Amendment rights to freedom of religion and to direct the upbringing of her children.251

The Von Tersch trial court conducted a substantial threat analysis and held that, based upon the court-appointed psychologist's testimony, the children should attend public school. In reversing the lower court, the Nebraska Supreme Court noted that no other evidence supported the idea that a religious school might harm the children. ${ }^{252}$ It concluded that "the trial court abused its discretion by intruding upon the right of a custodial parent to determine the nature and extent of educating a child ...."253

The Von Tersch case reveals several ways in which a court can misapply the substantial threat test. First, the trial court misinterpreted the children's lost opportunities for social interaction and athletic competition as a substantial threat of harm. ${ }^{254}$ Second, the trial court erred by effectively substituting the substantial threat test with the best interests of the child standard when it determined that the public school would offer the children more opportunity for social interaction and competition. 255

249. Zummo v. Zummo, 574 A.2d 1130, 1156 (Pa. Super. Ct. 1990) (citations omitted); see also Burrows v. Brady, 605 A.2d 1312, 1317-18 (R.I. 1992) ("religious training may provide a means to seek revenge and to limit a parent's visitation privileges. ... In these cases it is the children who ultimately suffer."); note 233 supra.

250. 455 N.W.2d 130 (Neb. 1990).

251. See id. at 134.

252. See id. at 136.

253. Id; cf. In re Marriage of Debenham, 896 P.2d 1098 (Kan. Ct. App. 1995) (affirming the trial court's denial of a request to modify a joint custody order to deny enrollment at a private religious school while noting the possibility of subsequent litigation on the same issue); McCown v. McCown, 649 A.2d 418 (N.J. Super. Ct. App. Div. 1994) (affirming rejection of an amendment to a divorce decree sought to enable the mother to send her children to Hebrew, rather than secular, school).

254. See Von Tersch, 455 N.W.2d at 136; see also Doolittle v. Doolittle, 525 N.W.2d 245, 248 (Neb. Ct. App. 1994) (finding no substantial threat of harm to children when Mennonite custodial mother kept children home from school after eighth grade). But see Gardini v. Moyer, 575 N.E.2d 423, 427 (Ohio 1991) (affirming that custodial mother substantially endangered children by removing them from elementary school).

255. See Von Tersch, 455 N.W.2d at 136. But see Burrows v. Brady, 605 A.2d 1312 (R.I. 1992) (applying best interests test to reject an appeal of an order giving the father custody of his children on Sunday, precluding the mother from including the children in her church services). Comparing the Von Tersch and Burrows cases demonstrates how courts manipulate the definition of "restriction" to increase their discretion in choosing which standards to apply. 
The Von Tersch decision also demonstrates that courts must scrutinize experts' opinions closely. For example, the Von Tersch trial court largely relied on a psychologist's hypothesis in making its finding of harm..$^{256}$ Courts must recognize that experts may also harbor personal biases toward minority religions or may employ standards for psychological evaluations that differ from the substantial threat, actual harm, best interests, and least restrictive means tests. ${ }^{257}$

Applying the NOAH procedure in these cases would lead to similar results but would better address the free exercise claims and reduce the appearance of bias. For example, a court applying the NOAH procedure to the Zummo facts would exclude all discussion of religious training until after it had made an initial custody determination. Then, finding no harm from a mixed religious upbringing, the court would allow both parents to share their religious views with the children.

A court applying the NOAH approach to the LeDoux facts would likely arrive at the same custody decision but would not base it on the parents' religious practices. The couple's inability to cooperate would likely lead to a custody award to the mother, but a court could not restrict the father's religious influence without first finding that this influence harmed the children and that such limitations were the least restrictive alternative. Substantiated by proffered evidence, such an explicit finding would reduce the appearance of bias. On the other hand, a NOAH court might determine that the son's psychological "stress" alone did not constitute harm. A court might instead enjoin each parent from disparaging the other's faith to the children.258

The Von Tersch decision demonstrates another advantage of the NOAH approach. A first phase NOAH analysis might find that the religious school provided an inferior educational environment compared to the local public school. The second phase analysis enables the mother to raise her free exercise and custodial rights arguments to send the children to an academically adequate religious school. Under NOAH, the court must accept a mother's choice of academic institutions unless it finds that her choice actually harms

256. See Von Tersch, 455 N.W.2d at 136.

257. See text accompanying notes $158,238,244-245$ supra. See, e.g., Varnum v. Varnum, 586 A.2d 1107, 1109-10 (Vt. 1990). Varnum affirmed the denial of custody to an abusive mother who was a Jehovah's Witness, relying, in part, on a psychologist's finding that the father "had 'a better attitude and concept of what children need to be raised in a normal fashion." Id. (emphasis added) (quoting the psychologist's evaluation). This reference to "normality" raises the concern that the psychologist considered Jehovah's Witnesses abnormal. See also Palmer v. Palmer, 545 N.W.2d 751 (Neb. 1996) (applying the Von Tersch substantial threat test to reverse a trial court order based largely on a guardian ad litem's testimony which limited the extent to which a custodial mother who is a Jehovah's Witness may involve her child in her religious activities).

258. See Peterson v. Peterson, 474 N.W.2d 862, 872 (Neb. 1991) (reversing the portion of the trial court's order prohibiting the mother from discussing religion with her children, but ordering mother to abstain from disparaging the father's religion). 
the children. The Von Tersch trial court's finding of harm and the appellate reversal of that finding highlight the fact that evaluations can differ. Nonetheless, the NOAH approach facilitates appellate review by requiring trial courts to make explicit findings from adduced evidence regarding actual harm to children. As applied to Von Tersch, this requirement would clarify the appellate court's grounds for reversal, if not change the original ruling. The father's right to share his religious beliefs with his children would remain unaffected. He simply could not frustrate the custodial mother's choice of school, absent a finding of harm.

\section{Relocation Cases}

In our mobile society, dissolution and modification cases often focus on the intended relocation of one parent. ${ }^{259}$ Sometimes, the party opposing the move exaggerates religious differences or the potential harm of religious practices in order to defeat the award of custody to the relocating parent or to secure a custody change, preventing the child from relocating. ${ }^{260}$ If the parent desiring to move belongs to a minority religion (or is not religious), the opposing parent may also gain a tactical advantage by exploiting religious prejudice. ${ }^{261}$ As a matter of policy, should courts consider religion when scrutinizing geographic relocations? 262

259. See, e.g., Larson v. Larson, 888 P.2d 719 (Utah Ct. App. 1994) (reversing a transfer of custody from the mother to the father because she intended to move out of state with the children and would be less likely to continue their religious training in the Mormon faith). The Larson court adhered to a standard of review that deferred to custodial control over child rearing, noting that "the compatibility of a parent's and child's religious beliefs is not a matter that the court should consider, absent some showing that religious beliefs are translated into actions that are harmful to a child's welfare." Id. at 724 .

260. See Kammerer v. Martin, No. 95-0665, 1995 WL 723249 (Wis. Ct. App. Dec. 7, 1995) (upholding grant of primary custody to father when mother announced plan to move and finding no First Amendment violation where the order restricts her right to interrupt school for religious events); see also Gancas v. Schultz, 683 A.2d 1207 (Pa. Super. Ct. 1996) (reversing a custody award to father when mother decided to move away, in part because trial court failed to give sufficient weight to the mother's interest in the continued religious training of the children); Ridge v. Ridge, No. 0117-92-4, 1993 WL 40963 (Va. Ct. App. Jan. 26, 1993) (affirming a trial court finding that, contrary to the mother's allegations, the father's religious practices did not injure the children and therefore would not prevent his moving away with them); Jennifer Ann Drobac, Demonized Women: Accused Witches in Recent Child Custody Cases (Apr. 4, 1997), <http://wwwleland.stanford.edu/class/law495/drobac.htm> (on file with the Stanford Law Review) (noting that divorce litigants may exploit religious differences to prevent a custodial parent's moving away).

261. Very similar situations occur when a party desires to remarry-especially if the remarriage involves a conversion to the new spouse's faith.

262. Relocation cases also implicate the constitutional right to interstate travel first recognized in Crandall v. Nevada, 73 U.S. 35 (6 Wall.) (1867) (the right to interstate travel is a necessary inference from the structure of the Constitution and the federal government); see also United States v. Guest, 383 U.S. 745, 758 (1966) ("freedom to travel throughout the United States has long been recognized as a basic right under the Constitution."). A discussion of the right to travel, as it relates to child custody cases, is beyond the scope of this note. However, the constitutional right to travel 
In Osteraas v. Osteraas, ${ }^{263}$ the Idaho Supreme Court dealt with blatant religious discrimination in remarriage and relocation. In Osteraas, the father moved for a change of custody when he learned that the mother intended to remarry and move out of state with the children. The trial court granted the custody change, finding that "the father would provide more stability and superior moral training," based on "the religion factor."264 The supreme court reversed, concluding that "the trial court abused its discretion in removing primary . . . custody from the mother based in part on that court's perception of her lack of religiousness." 265 The supreme court held that the trial court's ruling implicated both the Free Exercise and Establishment Clauses because when courts make custody contingent upon religious faith, they force parents to choose between their beliefs and their children. ${ }^{266}$

The Osteraas court employed language from both the Lemon and endorsement tests in finding an Establishment Clause violation, although it did not specifically name the endorsement test. The supreme court wrote:

The other effect of utilizing the religion factor in deciding custody disputes is that the courts will be seen as appearing to favor one religion over another, or favor religion in general as against no declared religion, thus using this factor would serve to establish such religion in contravention of the First Amendment establishment clause because it would have the primary effect of advancing religion, thus violating the second prong of the Lemon test. ${ }^{267}$

This passage demonstrates that the Osteraas court intended to avoid the appearance of endorsing or advancing any religion.

In relocation cases like Osteraas, an application of the NOAH procedure would prevent any discussion of a mother's lack of religious affiliations in the first phase. Presumably, the custodial parent would obtain permission to relocate and the other parent would be denied custody. The noncustodial parent could raise religion in the second phase. However, having to prove actual harm to the children based on the other parent's religious practices might discourage such an attempt.

complicates these relocation cases and should drive courts to be all the more diligent in examining the constitutional implications of custody cases involving relocation and religion.

263. 859 P.2d 948 (Idaho 1993).

264. Id. at 950 (quoting the trial court) (footnote omitted).

265. Id. at 954 .

266. See id. at 952 (citing Sherbert v. Verner, 374 U.S. 398 (1963)).

267. Id. at 953 (footnote omitted) (citing Lee v. Weisman, 505 U.S. 577, 586-88 (1992) and Lemon v. Kurtzman, 403 U.S. 602 (1971)) (noting that Lemon has not been overruled). 


\section{CONCLUSION}

Clarence Darrow declared, "The realm of religion ... is where knowledge leaves off, and where faith begins, and it never has needed the arm of the State for support, and wherever it has received it, it has harmed both the public and the religion that it would pretend to serve."268

Court consideration of religion in child custody cases currently harms more families than it benefits. The NOAH procedure would enable family law courts to consider religion only when absolutely required to serve a child's best interests or to protect against First Amendment violations. The NOAH bifurcated system would help to prevent religious bias from corrupting the initial custody determination. When evidence of parenting skills, and not religious bias, informs the custody decision, the child's best interests are served. Application of the NOAH procedure would encourage court acknowledgement of First Amendment rights, those stemming not only from the Free Exercise Clause but also from the Establishment Clause. Implementation might also reduce the number of appeals based on alleged First Amendment violations.

The NOAH procedure incorporates the actual harm standard currently employed in many states. This standard, if implemented in the bifurcated proceeding, would provide courts with an effective "negative rule" and guidance on when they can disqualify parents as custodians on the basis of their religious practices. This standard would foster compliance not only with the First Amendment but also with the Equal Protection Clause. Implementation of the NOAH procedure may help standardize custody determinations without overly compromising the court's discretionary function in determining the child's best interests. Standardization contributes to predictability in decisionmaking and may foster early dispute resolution. Thus, the need for the NOAH procedure is critical, not only to protect parents' religious rights, but also to protect children, their safety, and their relationships with both of their parents.

For thousands of years, persecution and intolerance have plagued those with religious beliefs. At the dawn of the new millennium, we must ensure that the next thousand years does not repeat such intolerance. The First Amendment is our beacon in this quest for religious liberty. We must adhere to its dictates in child custody cases, for the sake of the children, if for no one else.

268. Wolman v. Walter, 433 U.S. 229, 264 (1977) (Stevens, J., concurring) (quoting Tr. of Oral Arg. 7, Scopes v. State, 289 S.W. 363 (Tenn. 1927) (on file with the Clarence Darrow Papers, Library of Congress)). 


\section{TABLE I \\ ACTUAL HARM CASES}

\begin{tabular}{|c|c|c|c|}
\hline $\begin{array}{c}\text { Case / Religious } \\
\text { Issue }\end{array}$ & State / Citation & Standard(s) Used & $\begin{array}{c}\text { Miscellaneous } \\
\text { Notes }\end{array}$ \\
\hline $\begin{array}{l}\text { Kendall v. Kendall / } \\
\text { religious training, } \\
\text { father is } \\
\text { fundamentalist } \\
\text { Christian }\end{array}$ & $\begin{array}{l}\text { MA / } 687 \text { N.E.2d } \\
1228 \text { (Mass. 1997), } \\
\text { petition for cert. } \\
\text { filed, } 66 \text { U.S.L.W. } \\
3422 \text { (U.S. Apr. 27, } \\
\text { 1998) (No. 97- } \\
\text { 1756) }\end{array}$ & $\begin{array}{l}\text { actual substantial } \\
\text { harm / clear } \\
\text { evidence required }\end{array}$ & $\begin{array}{l}\text { cites to U.S. } \\
\text { Supreme Court } \\
\text { cases but doubts } \\
\text { continuing vitality } \\
\text { of Lemon }\end{array}$ \\
\hline $\begin{array}{l}\text { In re Marriage of } \\
\text { Weiss / contract to } \\
\text { raise child Jewish, } \\
\text { visitation } \\
\text { restrictions } \\
\end{array}$ & $\begin{array}{l}\text { CA / } 49 \text { Cal. Rptr. } \\
\text { 2d } 339 \text { (Ct. App.), } \\
\text { cert. denied, 117 S. } \\
\text { Ct. } 509 \text { (1996) }\end{array}$ & $\begin{array}{l}\text { clear and } \\
\text { affirmative / actual } \\
\text { harm / both parents } \\
\text { can teach religion }\end{array}$ & $\begin{array}{l}\text { cites to U.S. } \\
\text { Supreme Court } \\
\text { cases }\end{array}$ \\
\hline $\begin{array}{l}\text { Abbo v. Briskin / } \\
\text { religious training, } \\
\text { raise child Jewish }\end{array}$ & $\begin{array}{l}\text { FL / } 660 \text { So. 2d } \\
1157 \text { (Fla. Dist. Ct. } \\
\text { App. 1995) }\end{array}$ & $\begin{array}{l}\text { no consideration / } \\
\text { both parents can } \\
\text { teach religion }\end{array}$ & $\cdot$ \\
\hline $\begin{array}{l}\text { Jakab v. Jakab / } \\
\text { father is Jehovah's } \\
\text { Witness }\end{array}$ & $\begin{array}{l}\text { VT / 664 A.2d } 261 \\
\text { (Vt. 1995) }\end{array}$ & $\begin{array}{l}\text { actual harm / } \\
\text { custodian controls }\end{array}$ & physical abuse \\
\hline $\begin{array}{l}\text { Tsolumba v. } \\
\text { Tsolumba / mother } \\
\text { is member of } \\
\text { minority religion }\end{array}$ & $\begin{array}{l}\text { OH / No. } 16872 \text {, } \\
1995 \text { WL } 366378 \\
\text { (Ohio Ct. App. June } \\
21,1995 \text { ) }\end{array}$ & $\begin{array}{l}\text { will harm / actual } \\
\text { harm / can restrict } \\
\text { noncustodial parent }\end{array}$ & $\begin{array}{l}\text { cooperation } \\
\text { emphasized }\end{array}$ \\
\hline $\begin{array}{l}\text { Gago v. Acevedo / } \\
\text { mother is Jehovah's } \\
\text { Witness }\end{array}$ & $\begin{array}{l}\text { NY / 625 N.Y.S.2d } \\
250 \text { (App. Div. } \\
\text { 1995) }\end{array}$ & $\begin{array}{l}\text { actual harm found } \\
\text { but citation to } \\
\text { Aldous v. Aldous } \\
\text { (may consider } \\
\text { religion) }\end{array}$ & $\begin{array}{l}\text { Relevant Issue } \\
\text { case? / false } \\
\text { accusation of child } \\
\text { abuse / interference } \\
\text { in child's } \\
\text { relationship with } \\
\text { custodial parent }\end{array}$ \\
\hline $\begin{array}{l}\text { Sotnick v. Sotnick/ } \\
\text { contract to raise } \\
\text { child Jewish }\end{array}$ & $\begin{array}{l}\text { FL / } 650 \text { So. 2d } 157 \\
\text { (Fla. Dist. Ct. App. } \\
\text { 1995) }\end{array}$ & $\begin{array}{l}\text { no consideration / } \\
\text { both parents can } \\
\text { teach religion / can } \\
\text { restrict noncustodial } \\
\text { parent }\end{array}$ & \\
\hline $\begin{array}{l}\text { Leppert v. Leppert } \text { ' } \\
\text { mother is member } \\
\text { of minority religion }\end{array}$ & $\begin{array}{l}\text { ND / } 519 \text { N.W.2d } \\
287 \text { (N.D. 1994) }\end{array}$ & $\begin{array}{l}\text { clear and } \\
\text { affirmative / actual } \\
\text { harm }\end{array}$ & \\
\hline $\begin{array}{l}\text { deLevie v. deLevie / } \\
\text { school, both parents } \\
\text { Jewish-mother is } \\
\text { Orthodox }\end{array}$ & $\begin{array}{l}\text { OH / 621 N.E.2d } \\
594 \text { (Ohio Ct. } \\
\text { App.), jurisdictional } \\
\text { motion overruled by } \\
615 \text { N.E.2d } 1043 \\
\text { (Ohio 1993) }\end{array}$ & custodian controls & \\
\hline
\end{tabular}


TABLE I (CONT.)

ACTUAL HARM CASES

\begin{tabular}{|l|l|l|l||}
\hline \multicolumn{1}{|c|}{$\begin{array}{c}\text { Case / Religious } \\
\text { Issue }\end{array}$} & State / Citation & Standard(s) Used & \multicolumn{1}{|c|}{$\begin{array}{c}\text { Miscellaneous } \\
\text { Notes }\end{array}$} \\
\hline $\begin{array}{l}\text { Marjorie G. v. } \\
\text { Stephen G. / school, } \\
\text { religious training, } \\
\text { both Jewish -father } \\
\text { is conservative }\end{array}$ & $\begin{array}{l}\text { NY / 592 N.Y.S.2d } \\
209 \text { (Sup. Ct. 1992) }\end{array}$ & $\begin{array}{l}\text { will harm / } \\
\text { custodian controls / } \\
\text { both parents can } \\
\text { teach } \\
\text { religion/consider } \\
\text { values }\end{array}$ & restrictions imposed \\
\hline $\begin{array}{l}\text { Pater v. Pater / } \\
\text { mother is Jehovah's } \\
\text { Witness }\end{array}$ & $\begin{array}{l}\text { OH / 588 N.E.2d } \\
794 \text { (Ohio 1992) }\end{array}$ & $\begin{array}{l}\text { will harm / actual } \\
\text { harm / can restrict } \\
\text { noncustodial parent }\end{array}$ & $\begin{array}{l}\text { cites U.S. Supreme } \\
\text { Court cases }\end{array}$ \\
\hline $\begin{array}{l}\text { In re Marriage of } \\
\text { Craig / religious } \\
\text { training }\end{array}$ & $\begin{array}{l}\text { IA / 462 N.W.2d } \\
\text { 692 (Iowa Ct. App. } \\
\text { 1990) }\end{array}$ & $\begin{array}{l}\text { no consideration / } \\
\text { both parents can } \\
\text { teach }\end{array}$ & joint custody \\
\hline $\begin{array}{l}\text { Varnum v. } \\
\text { Varnum /mother is } \\
\text { Jehovah's Witness }\end{array}$ & $\begin{array}{l}\text { VT / 586 A.2d 1107 } \\
\text { (Vt. 1990) }\end{array}$ & $\begin{array}{l}\text { actual harm / least } \\
\text { restrictive means }\end{array}$ & physical abuse \\
\hline
\end{tabular}




\section{TABLE II}

ACTUAL HARM / MODIFICATIONS

\begin{tabular}{|c|c|c|c|}
\hline $\begin{array}{l}\text { Case / Religious } \\
\text { Issue } \\
\end{array}$ & State / Citation & Standards Used & $\begin{array}{l}\text { Miscellaneous } \\
\text { Notes }\end{array}$ \\
\hline $\begin{array}{l}\text { Larson v. Larson / } \\
\text { relocation, religious } \\
\text { training }\end{array}$ & $\begin{array}{l}\text { UT / 888 P.2d } 719 \\
\text { (Utah Ct. App. } \\
\text { 1994) }\end{array}$ & $\begin{array}{l}\text { consistency / } \\
\text { stability }\end{array}$ & \\
\hline $\begin{array}{l}\text { McCown v. } \\
\text { McCown / school, } \\
\text { mother is Jewish }\end{array}$ & $\begin{array}{l}\text { NJ / 649 A.2d } 418 \\
\text { (N.J. Super. Ct. } \\
\text { App. Div. 1994) }\end{array}$ & $\begin{array}{l}\text { no consideration / } \\
\text { both parents can } \\
\text { teach religion }\end{array}$ & - \\
\hline $\begin{array}{l}\text { In re Marriage of } \\
\text { Moore / religious } \\
\text { training }\end{array}$ & $\begin{array}{l}\text { IA / } 526 \text { N.W.2d } \\
335 \text { (Iowa Ct. App. } \\
1994 \text { ) }\end{array}$ & $\begin{array}{l}\text { no consideration / } \\
\text { both parents can } \\
\text { teach religion }\end{array}$ & $\begin{array}{l}\text { no material and } \\
\text { substantial change }\end{array}$ \\
\hline $\begin{array}{l}\text { Hoefers v. Jones / } \\
\text { who must pay for } \\
\text { school }\end{array}$ & $\begin{array}{l}\text { NJ / 672 A.2d } 1299 \\
\text { (N.J. Super. Ct. Ch. } \\
\text { Div. 1994), aff'd } \\
\text { per curiam, 672 } \\
\text { A.2d } 1177 \text { (N.J. } \\
\text { Super. Ct. App. Div. } \\
\text { 1996) }\end{array}$ & no religion issue & $\begin{array}{l}\text { breach of joint } \\
\text { custody agreement } \\
\text { regarding school }\end{array}$ \\
\hline $\begin{array}{l}\text { De Luca v. } \\
\text { De Luca / mother is } \\
\text { Jehovah's Witness }\end{array}$ & $\begin{array}{l}\text { NY / 609 N.Y.S.2d } \\
80 \text { (App. Div. 1994) }\end{array}$ & $\begin{array}{l}\text { actual harm / } \\
\text { custodian controls / } \\
\text { both parents can } \\
\text { teach religion }\end{array}$ & \\
\hline $\begin{array}{l}\text { Stafford v. } \\
\text { Stafford / visitation, } \\
\text { father is Mormon }\end{array}$ & $\begin{array}{l}\text { OH / No. L-93-026, } \\
1994 \text { WL 30515 } \\
\text { (Ohio Ct. App. Feb. } \\
4,1994 \text { ) }\end{array}$ & $\begin{array}{l}\text { will harm / actual } \\
\text { harm }\end{array}$ & \\
\hline $\begin{array}{l}\text { Osteraas v. } \\
\text { Osteraas / mother is } \\
\text { not religious }\end{array}$ & $\begin{array}{l}\text { ID / 859 P.2d } 948 \\
\text { (Idaho 1993) }\end{array}$ & $\begin{array}{l}\text { clear and } \\
\text { affirmative / actual } \\
\text { harm / consistency / } \\
\text { stability }\end{array}$ & $\begin{array}{l}\text { cites U.S. Supreme } \\
\text { Court cases }\end{array}$ \\
\hline $\begin{array}{l}\text { Kirchner v. } \\
\text { Caughey / religious } \\
\text { training, father is } \\
\text { Baptist }\end{array}$ & $\begin{array}{l}\text { MD / 606 A.2d } 257 \\
\text { (Md. 1992) }\end{array}$ & $\begin{array}{l}\text { actual harm / } \\
\text { conflates different } \\
\text { standards (risk, } \\
\text { substantial threat, } \\
\text { etc.) / clear and } \\
\text { affirmative } \\
\end{array}$ & \\
\hline $\begin{array}{l}\text { Lebovich v. } \\
\text { Wilson/ visitation } \\
\text { restrictions }\end{array}$ & $\begin{array}{l}\text { NY / } 547 \text { N.Y.S.2d } \\
54 \text { (App. Div. 1989) }\end{array}$ & actual harm & $\begin{array}{l}\text { very short opinion } \\
\text { with few details }\end{array}$ \\
\hline
\end{tabular}


TABLE III

SubSTANTIAL THREAT CASES

\begin{tabular}{|c|c|c|c|}
\hline $\begin{array}{l}\text { Case / Religious } \\
\text { Issue }\end{array}$ & State / Citation & Standards Used & $\begin{array}{c}\text { Miscellaneous } \\
\text { Notes }\end{array}$ \\
\hline $\begin{array}{l}\text { Reid v. Girouard / } \\
\text { restrictions }\end{array}$ & $\begin{array}{l}\text { NE / No. A-95- } \\
\text { 1144, 1996 WL } \\
\text { 380685 (Neb. Ct. } \\
\text { App. July 9, 1996) }\end{array}$ & $\begin{array}{l}\text { Immediate and } \\
\text { substantial/ } \\
\text { custodian controls }\end{array}$ & $\begin{array}{l}\text { cites to U.S. } \\
\text { Supreme Court } \\
\text { cases }\end{array}$ \\
\hline $\begin{array}{l}\text { Palmer v. Palmer I } \\
\text { mother is Jehovah's } \\
\text { Witness }\end{array}$ & $\begin{array}{l}\text { NE / } 545 \text { N.W.2d } \\
751 \text { (Neb. 1996) }\end{array}$ & $\begin{array}{l}\text { immediate and } \\
\text { substantial / } \\
\text { custodian controls / } \\
\text { both parents can } \\
\text { teach religion } \\
\end{array}$ & $\begin{array}{l}\text { cites to U.S. } \\
\text { Supreme Court } \\
\text { cases }\end{array}$ \\
\hline $\begin{array}{l}\text { In re Marriage of } \\
\text { Jensen-Branch / } \\
\text { religious training } \\
\text { restrictions, father is } \\
\text { member of minority } \\
\text { religion }\end{array}$ & $\begin{array}{l}\text { WA / } 899 \text { P.2d } 803 \\
\text { (Wash. Ct. App. } \\
\text { 1995) }\end{array}$ & $\begin{array}{l}\text { immediate and } \\
\text { substantial / both } \\
\text { parents can teach } \\
\text { religion }\end{array}$ & \\
\hline $\begin{array}{l}\text { In re Marriage of } \\
\text { Wang / father is } \\
\text { member of minority } \\
\text { religion }\end{array}$ & $\begin{array}{l}\text { MT / 896 P.2d } 450 \\
\text { (Mont. 1995) }\end{array}$ & $\begin{array}{l}\text { health would be } \\
\text { endangered / } \\
\text { emotional } \\
\text { development } \\
\text { impaired }\end{array}$ & \\
\hline $\begin{array}{l}\text { Garrett v. Garrett / } \\
\text { mother is Jehovah's } \\
\text { Witness }\end{array}$ & $\begin{array}{l}\text { NE / 527 N.W.2d } \\
213 \text { (Neb. Ct. App. } \\
1995 \text { ) }\end{array}$ & $\begin{array}{l}\text { immediate and } \\
\text { substantial / least } \\
\text { restrictive } \\
\text { alternative } \\
\end{array}$ & $\begin{array}{l}\text { cites to U.S. } \\
\text { Supreme Court } \\
\text { cases }\end{array}$ \\
\hline $\begin{array}{l}\text { In re Marriage of } \\
\text { Oswald / religious } \\
\text { training }\end{array}$ & $\begin{array}{l}\text { CO / 847 P.2d 251 } \\
\text { (Colo. Ct. App. } \\
\text { 1993) }\end{array}$ & $\begin{array}{l}\text { health would be } \\
\text { endangered / } \\
\text { emotional } \\
\text { development } \\
\text { impaired }\end{array}$ & $\begin{array}{l}\text { paternal } \\
\text { grandmother sued } \\
\text { for visitation so she } \\
\text { could take child to } \\
\text { church }\end{array}$ \\
\hline $\begin{array}{l}\text { Zummo v. Zummo / } \\
\text { contract to raise } \\
\text { child Jewish, } \\
\text { discrimination, } \\
\text { visitation } \\
\text { restrictions }\end{array}$ & $\begin{array}{l}\text { PA / 574 A.2d } 1130 \\
\text { (Pa. Super. Ct. } \\
\text { 1990) }\end{array}$ & $\begin{array}{l}\text { immediate and } \\
\text { substantial / both } \\
\text { parents can teach } \\
\text { religion / least } \\
\text { restrictive } \\
\text { alternative }\end{array}$ & $\begin{array}{l}\text { exhaustive analysis } \\
\text { of multitude of } \\
\text { issues, cites to U.S. } \\
\text { Supreme Court } \\
\text { cases }\end{array}$ \\
\hline $\begin{array}{l}\text { Von Tersch v. Von } \\
\text { Tersch / school }\end{array}$ & $\begin{array}{l}\text { NE / 455 N.W.2d } \\
130 \text { (Neb. 1990) }\end{array}$ & $\begin{array}{l}\text { immediate and } \\
\text { substantial }\end{array}$ & $\begin{array}{l}\text { cites to U.S. } \\
\text { Supreme Court } \\
\text { cases }\end{array}$ \\
\hline $\begin{array}{l}\text { LeDoux v. } \\
\text { LeDoux / father is } \\
\text { Jehovah's Witness }\end{array}$ & $\begin{array}{l}\text { NE / 452 N.W.2d } 1 \\
\text { (Neb. 1990) }\end{array}$ & $\begin{array}{l}\text { immediate and } \\
\text { substantial / } \\
\text { custodian controls / } \\
\text { can restrict } \\
\text { noncustodial } \\
\text { parent / least } \\
\text { restrictive } \\
\text { alternative } \\
\end{array}$ & $\begin{array}{l}\text { lengthy dissent: } \\
\text { clear and } \\
\text { affirmative / actual } \\
\text { harm / both parents } \\
\text { can teach religion, } \\
\text { cites to U.S. } \\
\text { Supreme Court } \\
\text { cases } \\
\end{array}$ \\
\hline
\end{tabular}


TABLE IV

SUBSTANTIAL THREAT CASES / MODIFICATIONS

\begin{tabular}{|c|c|c|c|}
\hline $\begin{array}{c}\text { Case / Religious } \\
\text { Issue }\end{array}$ & State / Citation & Standards Used & $\begin{array}{c}\text { Miscellaneous } \\
\text { Notes }\end{array}$ \\
\hline $\begin{array}{l}\text { Doolittle v. } \\
\text { Doolittle / school, } \\
\text { mother is } \\
\text { Mennonite }\end{array}$ & $\begin{array}{l}\text { NE/ } 525 \text { N.W.2d } \\
245 \text { (Neb. Ct. App. } \\
\text { 1994) }\end{array}$ & $\begin{array}{l}\text { immediate and } \\
\text { substantial/ } \\
\text { custodian controls }\end{array}$ & $\begin{array}{l}\text { cites to U.S. } \\
\text { Supreme Court } \\
\text { cases }\end{array}$ \\
\hline $\begin{array}{l}\text { Johnson v. Nation / } \\
\text { father is Evangelist }\end{array}$ & $\begin{array}{l}\text { IN/615 N.E.2d 141 } \\
\text { (Ind. Ct. App. 1993) }\end{array}$ & $\begin{array}{l}\text { health would be } \\
\text { endangered / } \\
\text { emotional } \\
\text { development } \\
\text { impaired / custodian } \\
\text { controls }\end{array}$ & $\begin{array}{l}\text { required } \\
\text { substantially } \\
\text { changed } \\
\text { circumstances, } \\
\text { cooperation } \\
\text { emphasized } \\
\end{array}$ \\
\hline $\begin{array}{l}\text { Bienenfeld v. } \\
\text { Bennett-White / } \\
\text { religious training }\end{array}$ & $\begin{array}{l}\text { MD / 605 A.2d } 172 \\
\text { (Md. Ct. Spec. App. } \\
\text { 1992) }\end{array}$ & $\begin{array}{l}\text { immediate and } \\
\text { substantial / both } \\
\text { can teach religion }\end{array}$ & $\begin{array}{l}\text { cites to U.S. } \\
\text { Supreme Court } \\
\text { cases }\end{array}$ \\
\hline $\begin{array}{l}\text { Burrows v. Brady / } \\
\text { visitation } \\
\text { restrictions }\end{array}$ & $\begin{array}{l}\text { RI/ 605 A.2d } 1312 \\
\text { (R.I. 1992) }\end{array}$ & $\begin{array}{l}\text { immediate and } \\
\text { substantial / both } \\
\text { can teach religion }\end{array}$ & cites Lemon \\
\hline $\begin{array}{l}\text { Peterson v. } \\
\text { Peterson / school, } \\
\text { mother is member } \\
\text { of minority religion }\end{array}$ & $\begin{array}{l}\text { NE / } 474 \text { N.W.2d } \\
862 \text { (Neb. 1991) }\end{array}$ & $\begin{array}{l}\text { immediate and } \\
\text { substantial / least } \\
\text { restrictive means }\end{array}$ & physical abuse \\
\hline $\begin{array}{l}\text { Gardini v. Moyer / } \\
\text { home school }\end{array}$ & $\begin{array}{l}\text { OH / } 575 \text { N.E.2d } \\
423 \text { (Ohio 1991) }\end{array}$ & $\begin{array}{l}\text { immediate and } \\
\text { substantial }\end{array}$ & \\
\hline
\end{tabular}




\section{TABLE V}

RISK CASES

\begin{tabular}{|l|l|l|l||}
\hline \begin{tabular}{|} 
Case / Religious \\
Issue
\end{tabular} & \multicolumn{1}{|c|}{ State / Citation } & Standards Used & \multicolumn{1}{|c|}{$\begin{array}{c}\text { Miscellaneous } \\
\text { Notes }\end{array}$} \\
\hline $\begin{array}{l}\text { Murphy v. Murphy / } \\
\text { father is member of } \\
\text { minority religion }\end{array}$ & $\begin{array}{l}\text { MN / No. C0-95- } \\
1363,1996 \mathrm{WL} \\
70978 \text { (Minn. Ct. } \\
\text { App. Feb. 20, 1996) }\end{array}$ & likely to endanger & physical abuse \\
\hline $\begin{array}{l}\text { Petersen v. Rogers / } \\
\text { parents are } \\
\text { members of } \\
\text { minority religion }\end{array}$ & $\begin{array}{l}\text { NC / 433 S.E.2d } \\
\text { 770 (N.C. Ct. App. } \\
\text { 1993), rev'd on } \\
\text { other grounds, 445 } \\
\text { S.E.2d 901 (N.C. } \\
\text { 1994) }\end{array}$ & $\begin{array}{l}\text { may adversely } \\
\text { affect }\end{array}$ & \\
\hline $\begin{array}{l}\text { In re Marriage of } \\
\text { Gersovitz / religious } \\
\text { training }\end{array}$ & $\begin{array}{l}\text { MT / 779 P.2d 883 } \\
\text { (Mont. 1989) }\end{array}$ & $\begin{array}{l}\text { may interfere with } \\
\text { general welfare }\end{array}$ & \\
\hline
\end{tabular}

TABLE VI

RISK CASES / MODIFICATIONS

\begin{tabular}{|c|c|c|c|}
\hline $\begin{array}{l}\text { Case / Religious } \\
\text { Issue }\end{array}$ & State / Citation & Standards Used & $\begin{array}{l}\text { Miscellaneous } \\
\text { Notes }\end{array}$ \\
\hline $\begin{array}{l}\text { MacLagan } \mathrm{v} \text {. } \\
\text { Klein / religious } \\
\text { training }\end{array}$ & $\begin{array}{l}\text { NC / } 473 \text { S.E.2d } \\
778 \text { (N.C. Ct. App. } \\
\text { 1996), review } \\
\text { denied by } 483 \\
\text { S.E.2d } 170 \text { (N.C. } \\
\text { 1997) }\end{array}$ & $\begin{array}{l}\text { May adversely } \\
\text { affect }\end{array}$ & $\begin{array}{l}\text { unmarried, joint } \\
\text { custody, but father } \\
\text { obtains sole right } \\
\text { regarding religious } \\
\text { training }\end{array}$ \\
\hline $\begin{array}{l}\text { Stolarick v. Novak / } \\
\text { father is member of } \\
\text { minority religion }\end{array}$ & $\begin{array}{l}\text { PA / } 584 \text { A.2d } 1034 \\
\text { (Pa. Super. Ct. } \\
\text { 1991) }\end{array}$ & $\begin{array}{l}\text { consider detrimental } \\
\text { affect }\end{array}$ & \\
\hline
\end{tabular}


TABLE VII

RELEVANT ISSUE CASES

\begin{tabular}{|c|c|c|c|}
\hline $\begin{array}{l}\text { Case / Religious } \\
\text { Issue }\end{array}$ & State / Citation & Standards Used & $\begin{array}{c}\begin{array}{c}\text { Miscellaneous } \\
\text { Notes }\end{array} \\
\end{array}$ \\
\hline $\begin{array}{l}\text { Gancas v. Schultz / } \\
\text { religious training }\end{array}$ & $\begin{array}{l}\text { PA / 683 A.2d } 1207 \\
\text { (Pa. Super. Ct. } \\
\text { 1996) }\end{array}$ & $\begin{array}{l}\text { consider spiritual } \\
\text { welfare of child, } \\
\text { religion as one } \\
\text { factor }\end{array}$ & \\
\hline $\begin{array}{l}\text { In re Marriage of } \\
\text { Debenham / school }\end{array}$ & $\begin{array}{l}\mathrm{KN} / 896 \text { P.2d } 1098 \\
\text { (Kan. Ct. App. } \\
\text { 1995) }\end{array}$ & consider stability & \\
\hline $\begin{array}{l}\text { Alaniz v. Alaniz I } \\
\text { mother is Jehovah's } \\
\text { Witness }\end{array}$ & $\begin{array}{l}\text { TX/867 S.W.2d } 54 \\
\text { (Tex. Ct. App. } \\
\text { 1993) }\end{array}$ & $\begin{array}{l}\text { consider if harmful, } \\
\text { illegal, immoral }\end{array}$ & $\begin{array}{l}\text { beliefs and practices } \\
\text { reviewed }\end{array}$ \\
\hline $\begin{array}{l}\text { Muhammad v. } \\
\text { Muhammad / father } \\
\text { is member of } \\
\text { minority religion }\end{array}$ & $\begin{array}{l}\text { MI / } 622 \text { So. 2d } \\
1239 \text { (Miss. 1993) }\end{array}$ & immoral & $\begin{array}{l}\text { cites to U.S. } \\
\text { Supreme Court } \\
\text { cases }\end{array}$ \\
\hline $\begin{array}{l}\text { Lange v. Lange / } \\
\text { father is member of } \\
\text { minority religion }\end{array}$ & $\begin{array}{l}\text { WI / 502 N.W.2d } \\
143 \text { (Wis. Ct. App. } \\
1993 \text { ) }\end{array}$ & $\begin{array}{l}\text { no test / custodian } \\
\text { controls / can } \\
\text { restrict noncustodial } \\
\text { parent }\end{array}$ & $\begin{array}{l}\text { cites to U.S. } \\
\text { Supreme Court } \\
\text { cases }\end{array}$ \\
\hline $\begin{array}{l}\text { Ridge v. Ridge / } \\
\text { relocation, mother } \\
\text { accuses father of } \\
\text { religious fanaticism }\end{array}$ & $\begin{array}{l}\text { VA. / No. 0117-92- } \\
\text { 4, 1993 WL 40963 } \\
\text { (Va. Ct. App. Jan. } \\
\text { 26, 1993) }\end{array}$ & $\begin{array}{l}\text { religion as one } \\
\text { factor }\end{array}$ & \\
\hline $\begin{array}{l}\text { Edwards v. } \\
\text { Edwards / mother } \\
\text { unstable in religious } \\
\text { beliefs }\end{array}$ & $\begin{array}{l}\text { MO / } 829 \text { S.W.2d } \\
91 \text { (Mo. Ct. App. } \\
\text { 1992) }\end{array}$ & best interests & stability \\
\hline $\begin{array}{l}\text { In re Marriage of } \\
\text { Bennett / contract to } \\
\text { raise child Jewish }\end{array}$ & $\begin{array}{l}\text { IL / } 587 \text { N.E.2d } 577 \\
\text { (Ill. App. Ct. 1992) }\end{array}$ & breach of contract & no contract found \\
\hline $\begin{array}{l}\text { Boylan v. Boylan / } \\
\text { religious training }\end{array}$ & $\begin{array}{l}\text { PA / } 577 \text { A.2d } 218 \\
\text { (Pa. Super. Ct. } \\
\text { 1990) }\end{array}$ & $\begin{array}{l}\text { considers but } \\
\text { neutrally }\end{array}$ & religious stability \\
\hline
\end{tabular}

TABLE VIII

RELEVANT ISSUES / MODIFICATIONS

\begin{tabular}{||l|l|l|l|}
\hline $\begin{array}{c}\text { Case / Religious } \\
\text { Issue }\end{array}$ & \multicolumn{1}{|c|}{ State / Citation } & Standards Used & \multicolumn{1}{|c|}{$\begin{array}{c}\text { Miscellaneous } \\
\text { Notes }\end{array}$} \\
\hline $\begin{array}{l}\text { Johns v. Johns / } \\
\text { religious training }\end{array}$ & $\begin{array}{l}\text { AR/918 S.W.2d } \\
728 \text { (Ark. Ct. App. } \\
1996)\end{array}$ & $\begin{array}{l}\text { moral values, may } \\
\text { adversely affect / } \\
\text { custodian controls / } \\
\text { can restrict } \\
\text { noncustodian }\end{array}$ & $\begin{array}{l}\text { father required to } \\
\text { take children to } \\
\text { church for "moral" } \\
\text { training }\end{array}$ \\
\hline $\begin{array}{l}\text { Kammerer v. } \\
\text { Martin / relocation, } \\
\text { mother is member } \\
\text { of minority religion }\end{array}$ & $\begin{array}{l}\text { WI/ No. 95-0665, } \\
\text { (W95 WL 723249 } \\
\text { 7, 1995) }\end{array}$ & $\begin{array}{l}\text { religion as one } \\
\text { factor / both parents } \\
\text { can teach religion }\end{array}$ & \\
\hline
\end{tabular}

